\title{
Neural Regulation of Bone and Bone Marrow
}

\author{
Maria Maryanovich, ${ }^{1,2}$ Shoichiro Takeishi, ${ }^{1,2}$ and Paul S. Frenette ${ }^{1,2,3}$ \\ ${ }^{1}$ Ruth L. and David S. Gottesman Institute for Stem Cell and Regenerative Medicine Research, Albert Einstein \\ College of Medicine, Bronx, New York 10461 \\ ${ }^{2}$ Department of Cell Biology, Albert Einstein College of Medicine, Bronx, New York 10461 \\ ${ }^{3}$ Department of Medicine, Albert Einstein College of Medicine, Bronx, New York 10461 \\ Correspondence: paul.frenette@einstein.yu.edu
}

Bones provide both skeletal scaffolding and space for hematopoiesis in its marrow. Previous work has shown that these functions were tightly regulated by the nervous system. The central and peripheral nervous systems tightly regulate compact bone remodeling, its metabolism, and hematopoietic homeostasis in the bone marrow (BM). Accumulating evidence indicates that the nervous system, which fine-tunes inflammatory responses and alterations in neural functions, may regulate autoimmune diseases. Neural signals also influence the progression of hematological malignancies such as acute and chronic myeloid leukemias. Here, we review the interplay of the nervous system with bone, BM, and immunity, and discuss future challenges to target hematological diseases through modulation of activity of the nervous system.

B ones constitute a part of the vertebrate skeleton, and this organ is formed during the fetal stage of development from either connective tissue (called intramembranous ossification) or cartilage (referred to as endochondral ossification) (Berendsen and Olsen 2015). After these processes, bones are consistently being created and replaced, known as remodeling, which is accomplished through bone resorption by osteoclasts and bone formation by osteoblasts (Manolagas 2000). Bones not only play a variety of mechanical roles, but also have synthetic aspects, one of which is production of blood cells from hematopoietic stem cells (HSCs) in the bone marrow (BM) (Frenette et al. 2013; Mendelson and Frenette 2014). Like most organs in vertebrates, these bone functions are regulated by its constituents and also by long-range signals such as leptin from the adipose tissue (Thomas et al. 1999; Cornish et al. 2002; Yue et al. 2016), glucocorticoids from the adrenal glands (Canalis and Delany 2002; Pierce et al. 2017), and parathyroid hormone from the parathyroid glands (Calvi et al. 2003). In addition to these factors, the nervous system has been suggested to regulate bone and BM since the discovery of innervation of the skeleton (Calvo 1968; Hanoun et al. 2015).

Genetic mutations and epigenetic alterations in hematopoietic cells in the BM lead to hematological malignancies, and recent studies suggested that neuropathy is involved in the progression of these diseases (Arranz et al. 2014; Hanoun et al. 2014). Moreover, previous

Editors: Gerard Karsenty and David T. Scadden

Additional Perspectives on Bone: A Regulator of Physiology available at www.perspectivesinmedicine.org

Copyright (C) 2018 Cold Spring Harbor Laboratory Press; all rights reserved; doi: 10.1101/cshperspect.a031344

Cite this article as Cold Spring Harb Perspect Med 2018;8:a031344 
M. Maryanovich et al.

studies have shown that the nervous system also modifies immune functions with deterioration of this mechanism being associated with autoimmune diseases (Sternberg 2006). In this review, we summarize such neuronal regulation of bone, hematopoiesis, and immune functions as well as provide perspectives to target hematological diseases by modulating the nervous system.

\section{NEURAL REGULATION OF BONE}

The skeleton, in addition to being a structural organ and a major site of mineral storage in the body, also serves as an endocrine organ, secreting factors that control the function of other tissues. In parallel bone-derived regulators of bone homeostasis, skeletal functions are also regulated by long-range signals originating from the nervous system.

The central nervous system (CNS) coordinates voluntary and involuntary input transmitted to tissues by peripheral nerves. The involuntary responses are regulated by the autonomic nervous system (ANS) comprised of two distinct branches (Hanoun et al. 2015). The first is the sympathetic nervous system (SNS) that emerges from the thoracolumbar spinal cord, and prepares the body for alert situations by increasing heart rates and the contractility of myocytes, while diverting blood flow away from the gastrointestinal (GI) tract. The second is the parasympathetic nervous system (PNS) emerging from the cranial nerves and the sacral spinal cord (Fig. 1). In contrast to the SNS, the PNS decreases heart rates and muscle contractility, while increasing the blood flow to the GI tract, thereby promoting restive and digestive responses. These ANS branches differ in the neurotransmitters used at the effector organs. The SNS releases norepinephrine ([NE] also referred to as noradrenaline) to send signals, whereas acetylcholine $(\mathrm{ACh})$ is used as a transmitter in the PNS. NE binds to two forms of the adrenergic receptor (AR), $\alpha$ and $\beta$, which are further divided into subtypes $\alpha 1$ and $\alpha 2$, and $\beta 1, \beta 2$, and $\beta 3$, respectively. All of these are G-protein-coupled receptors: $\alpha 1$ is Gq-coupled, $\alpha 2$ is Gi-coupled, and $\beta 1-\beta 3$ are Gs-coupled. On the other hand,
ACh from the PNS binds to two receptor subtypes, nicotinic and muscarinic cholinergic receptors, which are classified into N1-N2 and M1-M5, respectively. Besides the ANS, the cross talk between the CNS and periphery is also exerted by the hypothalamic-pituitary-adrenal (HPA) axis, in which glucocorticoids eventually released from the adrenal cortex into the circulation exert functions by binding to their intracellular receptors in tissues and regulating transcription of various genes (Revollo and Cidlowski 2009).

Integration of skeletal functions with other organs, to maintain total body homeostasis, is coordinated by the CNS and peripheral nerves originating from the ANS. The first histological evidence of skeletal innervation came from the pioneering studies of Calvo (1968), providing evidence of bone innervation by nerve fibers, through bone nutrient foramina, with a distribution pattern recapitulating the nutrient artery. Many studies since then have confirmed and extended Calvo's observations and describe both autonomic and sensory nerve innervation of the skeleton, reaching deep into the BM space (Calvo 1968).

\section{Central Regulation of Skeletal Homeostasis}

The initial indication that the CNS can control bone turnover came from the studies of leptin, a polypeptide hormone exclusively produced by the adipose tissue (Zhang et al. 1994). Leptin was originally identified to control body weight and gonadal function through its action on the arcuate nucleus of the hypothalamus (Zhang et al. 1994; Halaas et al. 1995; Friedman and Halaas 1998). Studies focusing on peripheral action of leptin and its receptor on bone cells suggested that leptin acted as an osteogenic factor by activating its receptor on bone osteolineage cells (Thomas et al. 1999; Cornish et al. 2002). Other studies, however, suggest that the signaling of leptin in the CNS regulates bone mass, wherein intracerebroventricular (ICV) infusion of leptin corrected the high bone mass observed in ob/ob mice or reduced bone mass when infused into wild-type mice, highlighting the central function of leptin in 


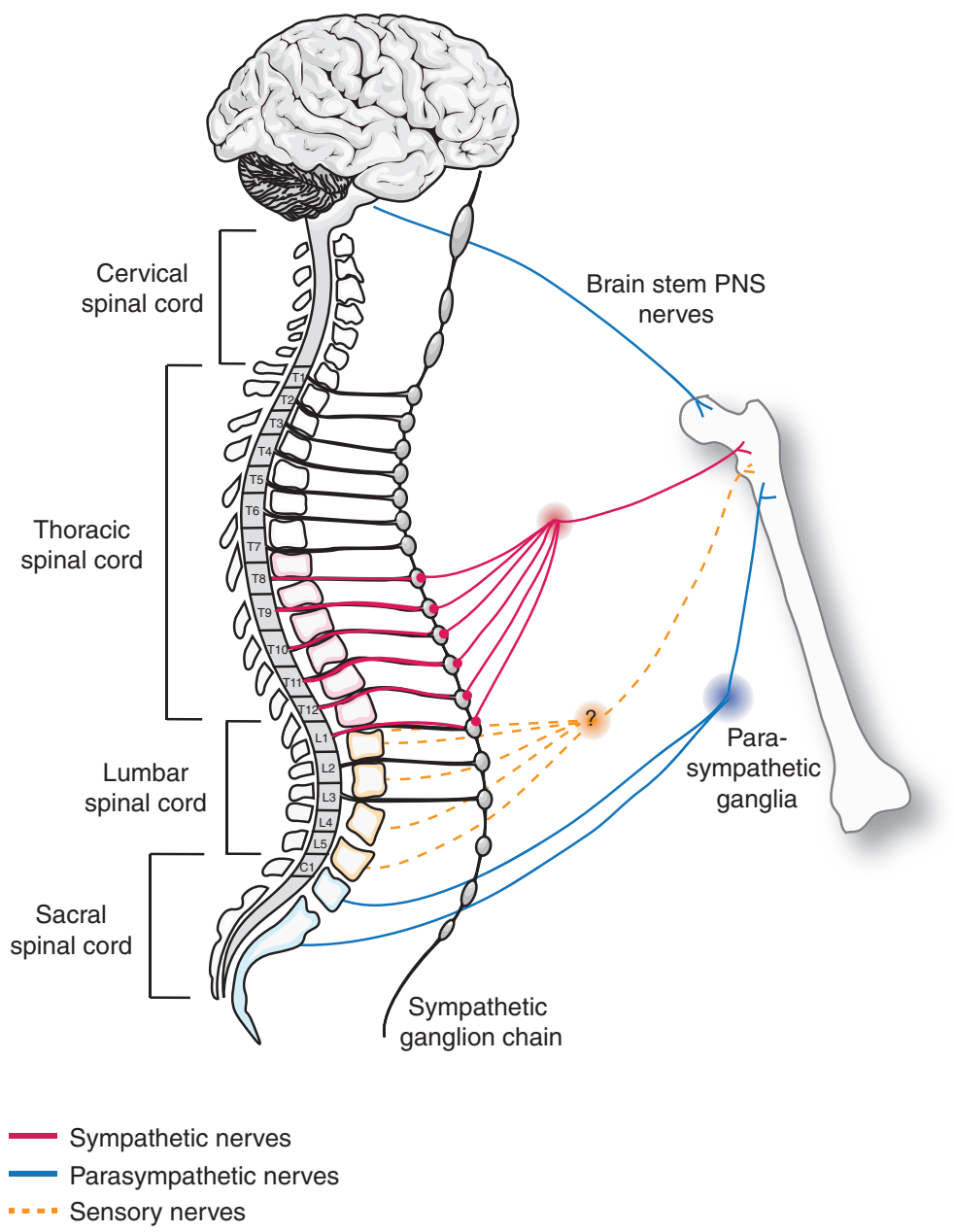

Figure 1. Schematic illustration depicting the anatomic origin of sympathetic, parasympathetic, and sensory innervation of bone. PNS, Parasympathetic nervous system.

controlling skeletal homeostasis (Fig. 2) (Ducy et al. 2000).

Another centrally acting neurotransmitter linked to bone homeostasis is serotonin (5-hydroxytryptamine [5-HT]), which was found to differentially regulate bone mass depending on its site of action (Walther et al. 2003). Serotonin is primarily produced in the CNS by tryptophan hydroxylase 2 (Tph2), or in the GI tract by tryptophan hydroxylase 1 (Tph1) that contributes to blood serotonin levels, which does not cross the blood-brain barrier and does not contribute to its role as a neurotransmitter in the brain (Dimitri and Rosen 2017). In the CNS, serotonin mainly functions as a mood stabilizer supporting cognitive function, emotional well-being, and happiness (Schmitt et al. 2006; Alenina and Klempin 2015). One of the initial links of serotonin and bone homeostasis came from clinical studies of depression patients with reduced serotonergic tone or patients taking selective serotonin reuptake inhibitors (SSRIs) as treatment of depression. These studies revealed that serotonergic deficiency or chronic use of SSRIs increased the risk of osteoporotic bone fractures (Feuer et al. 2015; Sheu et al. 2015; Rauma et al. 2016). Further validation of these findings came from studies in mice in which pharmacological inhibition or genetic deletion of the 5-HT transporter, responsible for cellular serotonin reup- 
M. Maryanovich et al.



Figure 2. Schematic illustration summarizing central nervous system (CNS) regulators of bone remodeling.

take, resulted in a reduced bone mass phenotype (Warden and Haney 2008; Warden et al. 2010). Neurotransmitter profiling in the brain of $o b / o b$ mice revealed that leptin deficiency induced accumulation of brain stem serotonin levels and that deletion of $T p h 2$ in mice $\left(T p h 2^{-l-}\right)$ results in loss of bone mass attributable to increased bone resorption and decreased bone formation (Yadav et al. 2009). Specific deletion of leptin receptor (Lepror ObRb) in serotonergic neurons by crossing Obrb-floxed mice with serotonin transporter promoter (Sert-Cre) or Tph2-Cre lines resulted in morbid obesity associated with dramatic increase in bone mass, reminiscent of the Lepr deficiency $(d b / d b)$, confirming that the mechanism of leptin skeletal metabolism is by inhibition of serotonin synthesis in the brain stem. Moreover, loss of central Tph2 reduced adiposity owing to reduced appetite and increased energy expenditure, similar to the $o b /$ $o b$ leptin-deficient mouse model (Yadav et al. 2009). These findings, thus, suggest a central role for serotonin in the CNS, downstream from leptin, in regulating appetite, energy expenditure, and bone metabolism (Fig. 2).

Along its role in the CNS, peripheral serotonin synthesized in the GI tract by enterochromaffin cells in the duodenum has also been shown to regulate bone homeostasis. The role of peripheral serotonin on bone homeostasis has emerged from studies of LRP5, an LDL-receptor-related protein 5 , a coreceptor for Wnt ligands and one of the most studied regulators of bone homeostasis (Baron and Rawadi 2007). Mutations in LRP5 are associated with dramatic deregulation of bone formation, in which lossof-function mutations cause severe bone loss and osteoporosis pseudoglioma, and gain-offunction mutations increase bone mass (Gong et al. 2001; Boyden et al. 2002; Little et al. 2002). Interestingly, deletion of Lrp5 gene in mice $\left(L r p 5^{-/-}\right)$increased expression of $T p h 1$ in both bones and the gut and significantly elevated serotonin serum levels (Yadav et al. 2008). Gut-specific deletion of Lrp5 recapitulated the phenotypes of low bone mass in $\mathrm{Lrp5}^{-/-}$mice, revealing a novel gut-to-bone exocrine axis involving serotonin (Kode et al. 2014). Once released into the bloodstream, serotonin regulates bone remodeling by direct signaling to its receptor 5-hydroxytryptamine receptor 1B (HTR1B) expressed by osteoblasts, inhibiting activation of the cyclic adenosine monophosphate (cAMP) response element-binding (CREB) transcription factor, whose activity is necessary for normal osteoblast proliferation (Yadav et al. 2008).

Similar to leptin, neuropeptide Y (NPY) is highly expressed in the hypothalamic arcuate nucleus where it regulates appetite downstream from leptin (Stanley et al. 1986; Erickson et al. 1996). NPY signals are mediated via five major NPY receptors (Y1-5), of which both Y1 and Y2 receptors, abundant in the CNS, have been shown to regulate bone mass (Horsnell and Baldock 2016). Peripheral expression of NPY receptors in adipocytes, osteoblasts, and osteocytes have also been reported (Kuo et al. 2007; Lundberg et al. 2007; Lee et al. 2010). Initial studies showed that ICV infusion of NPY to the cerebrospinal fluid, in contrast to leptin, induced loss of bone mass, indicating that NPY and leptin do not antagonize each other's function in the CNS (Ducy et al. 2000). Mice deficient in NPY $\left(\mathrm{NPY}^{--}\right)$or Y receptor $2\left(\mathrm{Y2}^{-/-}\right)$ showed significantly increased bone mass associated with increased osteoblast activity and increased expression of osteogenic transcription factors, Runx2 and Osterix (Osx), compared with wild-type controls (Baldock et al. 2002, 
2005, 2009). The bone phenotype observed in $Y 2^{-1-}$ mice was independent of leptin signaling or expression of $\mathrm{Y} 2$ receptors in the osteolineage cells, highlighting the critical role of central Y2 in regulating bone remodeling. The Y1 receptor has also been implicated in bone remodeling in that $Y 1^{-/-}$mice showed increased bone mass (Baldock et al. 2007). This function, however, was attributed to peripherally expressed Y1, because hypothalamic deletion of Y1 resulted in no apparent bone phenotype. In addition to the aforementioned central regulators of bone remodeling, the number of central neuropeptides and hormones involved in skeletal homeostasis is expanding. Centrally acting cocaine- and amphetamine-regulated transcript (CART), neuromedin $U$, melatonin, adiponectin, and the endocannabinoid system have all been implicated to play diverse roles in bone remodeling. Owing to the limited focus of this review on these neuropeptides, a thorough review of these molecules and pathways can be found elsewhere (Wee et al. 2016; Dimitri and Rosen 2017).

\section{Autonomic Control of the Bone Remodeling}

The SNS represents the major arm of the CNS, controlling skeletal homeostasis, mainly by action of ARs expressed on target bone cells. Preganglionic neurons from the thoracolumbar spinal cord form sympathetic ganglia from which postganglionic neurons innervate target organs (Fig. 1). Immunofluorescence imaging studies have detected the presence of postganglionic neurons in bone by detection of the neuromodulators that they express. Peripheral sympathetic innervation of bone can be visualized by staining for tyrosine hydroxylase $(\mathrm{TH})$, a ratelimiting enzyme involved in catecholamine synthesis or NPY that is commonly expressed by sympathetic neurons (Bjurholm et al. 1988b). $\mathrm{TH}$-expressing nerve fibers closely associate and ensheathe blood vessels and can be detected in the periosteum, mineralized bone, and further innervating the BM hematopoietic cavity (Bellinger et al. 1992). The pattern of nerve distribution in the bone microenvironment-where large nerves accompany arteries that feed the bone at multiple locations-suggests that most bone-associated cells do not come in direct contact with nerve fibers and that nerve signal transduction is nonsynaptic. In this scenario, overflow of NE from vascular nerves may signal to ARs expressed on bone cells. Evidence for the role of ARs in skeletal metabolism has emerged from studies in rodents, in which pharmacologic perturbation of $\beta$-adrenergic signals has impacted bone mass. Significant bone loss was detected in mice treated with the $\beta$-adrenergic agonist isoproterenol, whereas treatment with propranolol (nonselective $\beta$-adrenergic antagonist) had beneficial effects on bone homeostasis (Takeda et al. 2002).

Bone remodeling comprises two phases: bone resorption, which is facilitated by osteoclasts, and bone formation mediated by osteoblasts. $\beta$-ARs are the major transducers of adrenergic signals in peripheral tissues. In the bone, $\beta 2$-ARs are primarily expressed by osteoblasts, and expression has also been detected in bone-forming osteocytes, osteoclasts, and chondrocytes, suggesting neural control of most bone and cartilage cell types (Elefteriou et al. 2014). It still remains unclear which particular bone cell type is most responsive to SNS signals. Evidence supporting the cross talk between leptin, SNS, and $\beta 2$-AR signaling in bone remodeling came from studies of mice deficient in dopamine hydroxylase $(\mathrm{DBH})$ in which the inability to synthesize catecholamines led to bone mass accrual (Takeda et al. 2002). Moreover, clinical studies of patients with reflex sympathetic dystrophy, associated with increased sympathetic tone, were found to produce osteoporosis, which in some cases can be rectified by antagonizing $\beta$ adrenergic signaling (Schwartzman 2000). A direct link between the SNS signaling and bone remodeling emerged from studies of $\beta 2$-AR-deficient mice $\left(A d r b 2^{-/-}\right)$. Similar to deletion of leptin or Lepr, $\beta 2$-AR deletion resulted in increased bone mass phenotype; however, ICV infusion of leptin in these mice failed to rescue the increased bone mass (Elefteriou et al. 2005; Bonnet et al. 2008). Further analysis of $A d r b 2^{-/-}$ mice revealed that the SNS favored bone resorption by inducing production of osteoblast-derived osteoclast differentiation factor Rankl (Elefteriou et al. 2005). Interestingly, unlike in 
M. Maryanovich et al.

ob/ob mice, Adrb2 $2^{-/-}$did not induce weight gain or gonadal dysfunction, suggesting that $\beta 2$-AR signaling specifically controlled skeletal turnover. Finally, osteoblast-specific deletion of $\beta 2$-ARs, by crossing mice that express the $\beta 2$-AR-floxed allele with mice carrying the $\alpha 1$ Col1-Cre, recapitulated the high bone mass phenotype of $A d r b 2^{-l-}$ mice, confirming that $\beta 2$-ARs are major mediators of SNS signals by osteoblasts (Kajimura et al. 2011). Along with $\beta 2$-ARs, other ARs have been implicated to play a role in both central and peripheral control of skeletal homeostasis. A thorough review of these molecules and their functions is reviewed elsewhere (Dimitri and Rosen 2017).

Similar to the SNS, the PNS has also been suggested to innervate the skeleton. Emerging from cranial nerves and the sacral spinal cord (Fig. 1), PNS nerves can be detected to penetrate the bone distal femoral metaphysis by immunostaining for choline acetyltransferase (ChAT) (Artico et al. 2002; Bajayo et al. 2012), an enzyme responsible for synthesis of acetylcholine. Peripheral cholinergic signaling can increase bone mass via activation of nicotinic receptors $\left(\alpha_{2} \mathrm{nAChR}\right)$ expressed by osteoclasts, inhibiting bone resorption by induction of osteoclast apoptosis (Bajayo et al. 2012). Moreover, activation of nAChRs by specific agonists can induce osteoblast proliferation, further contributing to bone mass accrual. However, deletion of $\alpha_{2} \mathrm{nAChR}$ in mice leads to osteoclast-driven loss of bone mass (Bajayo et al. 2012). In addition to nAChRs, muscarinic receptors (mAChRs) have also been implicated in skeletal homeostasis and shown to be expressed by bone cells (Liu et al. 2011; Kauschke et al. 2015). There are five mAChRs (Chrm1-5) of which type 3 muscarinic receptor (Chrm3) was shown to be crucial for bone remodeling. Deletion of Chrm 3 in mice $\left(\mathrm{Chrm}^{-/-}\right)$is associated with low bone mass phenotype; however, unlike ARs or nAChRs expressed by bone cells, Chrm3 expression and activity in the brain stem affected bone remodeling by suppressing the sympathetic tone (Shi et al. 2010). Interestingly, central expression of interleukin 1 (IL-1) cytokine was shown to be a key positive regulator of parasympathetic tone (Bajayo et al. 2012), illustrating the antagonistic relationship between the SNS and PNS in controlling skeletal homeostasis (Fig. 2).

\section{Sensory Innervation of the Bone}

The presence of sensory nerves in the bone was documented by detection of either substance $\mathrm{P}$ (SP) or calcitonin gene-related peptide (CGRP)positive nerve fibers (Bjurholm et al. 1988). Femoral sensory nerves originate from the dorsal root ganglia of the lumbar spinal cord and innervate mineralized bone, periosteum, and further penetrate the BM (Fig. 1) (Bjurholm et al. 1988a; Yoshino et al. 2014). The role of sensory innervation on skeletal homeostasis emerged from denervation studies in which capsaicin was used to destroy sensory nerves. These studies showed that denervation of sensory nerves induced reduction in bone mineral density attributable to increased osteoclast activity (Offley et al. 2005; Ding et al. 2010). Interestingly, in vitro studies showed that CGRP may act on osteoclasts, osteoblasts, and other stromal cells to regulate bone formation. Treatments of osteoclast or BM cultures with CGRP inhibited osteoclast formation and activity, inhibiting bone resorption and promoting proliferation and osteogenic differentiations of BM mesenchymal stem cell (MSC) cultures, leading to increased mineralization (Zaidi et al. 1987; Cornish et al. 2001; Ishizuka et al. 2005; Wang et al. 2010; Liang et al. 2015).

\section{NEURONAL REGULATION OF BONE MARROW}

Autonomic nerves reaching the bones also penetrate the BM, reaching deep into regions of hematopoietic activity. Out of all the autonomic nerves that reach the bone, it was shown that only close to $5 \%$ of SNS nerves actually penetrate the BM (Jung et al. 2017). However, taking into account the relative volume of the bone cavity compared with the periosteal bone region, the BM contains the highest density of autonomic nerves (Mach et al. 2002).

The BM microenvironment contains specialized niches responsible for maintenance of HSCs, which generate all blood cell lineages 
throughout life. HSC niches are composed of specialized cell types derived from mesenchymal, endothelial, stromal, and neural origin that integrate membrane-bound and secreted signals controlling quiescence, proliferation, and retention of HSCs (Fig. 3) (Asada et al. 2017b). At steady state, most HSCs are maintained in a quiescent state within their niche. In response to stress (such as radiation injury, chemotherapy, or infection), HSCs become activated to restore homeostasis (Wilson et al. 2009). The SNS represents a critical regulatory component of the $\mathrm{BM}$ microenvironment, where sympathetic nerve fibers and other neural crest derivatives form a niche, essential for maintaining HSC behavior during both homeostasis and stress situations (Hanoun et al. 2015). To date, the role of the PNS has largely been attributed to bone remodeling and very little is known about cholinergic signaling affecting HSCs or their microenvironment. A recent study revealed that Chrm1 promotes HSC mobilization from the BM but it did not act from the BM microenvironment but rather from the CNS where it activates the HPA axis, releasing glucocorticoids that prime HSCs to migrate (Pierce et al. 2017).

As previously mentioned, sensory nerves that reach the bone are also detected in the BM (Bjurholm et al. 1988; Hill and Elde 1991; Mach et al. 2002). Ablation of sensory nerves with capsaicin was reported to reduce BM cellularity and blood counts, suggesting a regulatory role for sensory nerves in hematopoiesis (Broome and Miyan 2000). In vitro cultures of hematopoietic progenitors with sensory neuro-

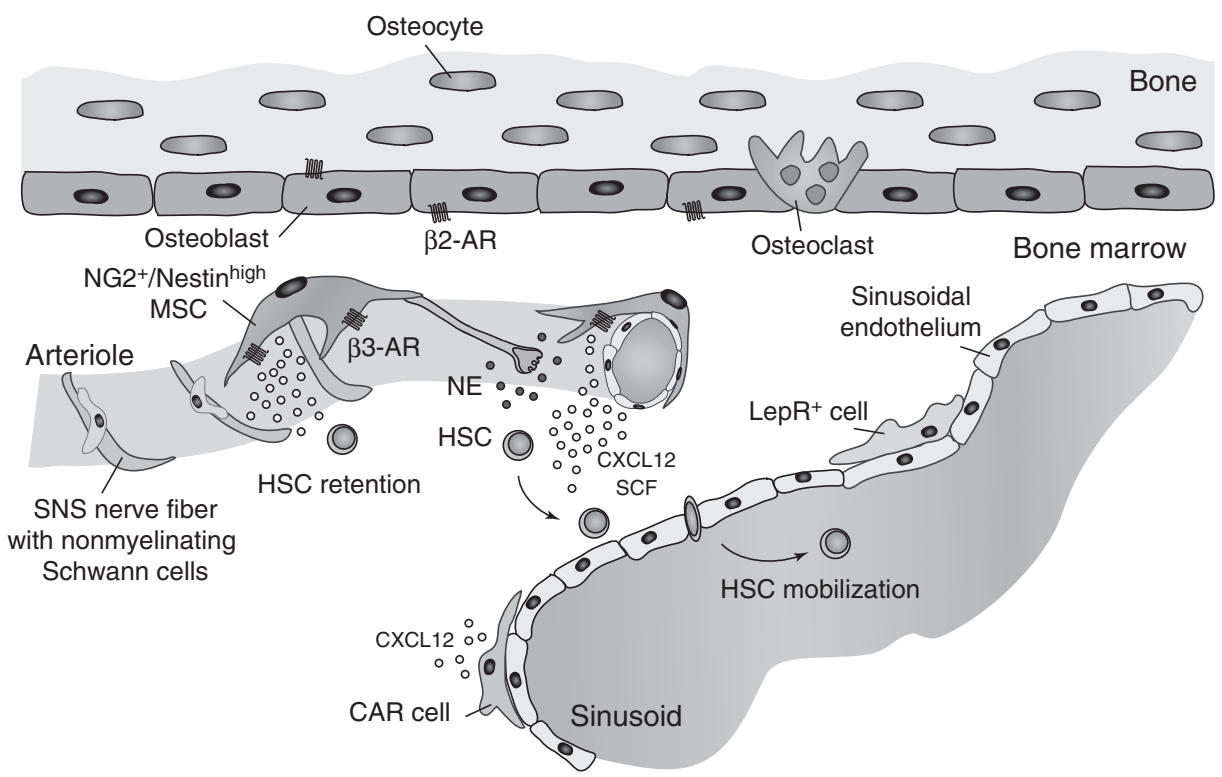

Figure 3. Autonomic signals modulate hematopoietic stem cell (HSC) niche homeostasis at steady state. Peripheral sympathetic neurons are one of the main components of a healthy HSC niche. Circadian noradrenaline secretion from sympathetic nerve terminals leads to circadian expression of C-X-C chemokine ligand 12 (CXCL12) by Nestin ${ }^{\text {high }} / \mathrm{NG2}^{+}$perivascular mesenchymal stem cells (MSCs), resulting in rhythmic release of HSCs to the periphery. The adrenergic signals in this case are mediated through the $\beta 3$-adrenergic receptor (AR). Secretion of HSC maintenance factors such as stem cell factor (SCF) and CXCL12 by Nestin ${ }^{\text {high }} / \mathrm{NG}^{+}{ }^{+}$MSCs keeps a subset of HSCs quiescent and in close association with arteriolar blood vessels, ensheathed with sympathetic nervous system (SNS) nerve fibers. When activated, HSCs relocate near the Nestin ${ }^{\text {low }}$ leptin receptor (LepR)-expressing perisinusoidal area. SNS signals also regulate bone formation via $\beta 2$-AR signaling in osteoblasts. In addition to SNS nerves, nonmyelinating Schwann cells also maintain HSC dormancy through activation of the transforming growth factor $\beta$ (TGF- $\beta$ )/SMAD signaling. 
M. Maryanovich et al.

peptides SP and CGRP stimulated progenitor activity (Rameshwar and Gascon 1995; Broome and Miyan 2000), partly explaining the impaired blood production following capsaicin administration. Although these studies suggest a direct involvement of sensory neuropeptides in regulating HSC and progenitor activity in the BM, further studies are required to determine the extent of sensory nerves cross talk with the autonomic control of hematopoiesis.

\section{Neuronal Components of the HSC Niche}

A niche responsible for maintaining HSCs in the $\mathrm{BM}$ was initially proposed to be composed of osteolineage-derived cells (Calvi et al. 2003; Zhang et al. 2003). Bone-lining osteoblasts and other osteolineage cell types were proposed to maintain HSCs through secretion of angiopoietin-1 (Arai et al. 2004) and osteopontin (Opn) (Nilsson et al. 2005; Stier et al. 2005). More recent studies, however, have found that deletion of key HSC maintenance factors (C-X-C chemokine ligand 12 [CXCL12] and stem cell factor [SCF] cytokines) in mature osteoblasts (expressing osteocalcin [Bglap]-Cre or Col2.3-Cre) had a negligible effect on HSC maintenance (Ding et al. 2012; Ding and Morrison 2013). These data support the notion that osteoblasts do not directly support HSCs, but rather osteolineage cells were suggested to create a niche for early lymphoid progenitors, implying that HSCs and restricted progenitors occupy distinct niches in the BM microenvironment. Evidence for this came from immunofluorescence studies of BM sections, which revealed that lineage Il7R $\alpha^{+}$lymphoid progenitors were predominantly localized to the endosteal region of the BM, close to osteoblasts and that genetic ablation of CXCL12 in osteoblasts (using the Col2.3-Cre model) depleted common lymphoid progenitors (CLPs) and Il7R $\alpha^{+}$lymphoid-primed multipotent progenitors (LMPPs) without affecting HSC homeostasis (Zhu et al. 2007; Ding and Morrison 2013). However, a more recent study showed that a large percentage of CLPs were localized further than $30 \mu \mathrm{m}$ away from the endosteal region and no IL-7 production by osteoblasts could be detected. Furthermore, conditional deletion of $\mathrm{Il7}$ in osteoblasts using the Col2.3-Cre model did not affect B lymphopoiesis. In contrast, IL-7 was predominantly produced by a subset of CXCL12-abundant reticular (CAR) cells, which are located in perivascular regions of the BM (Cordeiro Gomes et al. 2016).

Recent advances in imaging technologies have revealed that HSCs were primarily located in perivascular areas of the BM in close proximity to endothelial cells and perivascular stromal cells (Entschladen et al. 2004; Kiel et al. 2005; Mendez-Ferrer et al. 2010b; Ding et al. 2012; Kunisaki et al. 2013; Acar et al. 2015; Itkin et al. 2016; Kusumbe et al. 2016). The BM vascular architecture is composed of two types of blood vessels: (1) sinusoidal blood vessels, fenestrated structures evenly distributed in the BM space, and (2) arteriolar blood vessels, primarily located near the endosteal bone region and highly innervated by the SNS (Fig. 3) (Kunisaki et al. 2013; Sivaraj and Adams 2016). The endothelial cell network contributes to niche activity and supports HSCs by secreting essential factors such as CXCL12 and SCF (also known as Kitl) (Kiel et al. 2005; Ding et al. 2012; Ding and Morrison 2013). Interestingly, a recent study of vascular niche aging failed to show that rejuvenation of vasculature could rescue age-related HSC attrition (Kusumbe et al. 2016), highlighting that other niche regulators may be required to maintain HSCs throughout life. SNS nerves and perivascular stromal cells, expressing a type VI intermediate filament protein Nestin, ensheathe arterioles forming structural networks termed the neuroreticular complex (Yamazaki and Allen 1990; Mendez-Ferrer et al. 2010b; Kunisaki et al. 2013). Interestingly, a subset of quiescent HSCs is found to be closely associated with these arteriolar structures (Mendez-Ferrer et al. 2010b; Kunisaki et al. 2013; Itkin et al. 2016; Kusumbe et al. 2016), placing sympathetic nerves as central components of the HSC niche. Nestin-expressing perivascular cells, which are highly enriched for HSC maintenance and retention factors, including Vcam1, Cxcl12, Angpt1, Scf, and Opn, were shown to contain BM MSC activity, giving rise to osteogenic, adipogenic, and chondrogenic lineages (MendezFerrer et al. 2010b; Pinho et al. 2013). These 
$\mathrm{Nestin}^{+}$cells can also be labeled with the NG2 pericyte marker-specific $\mathrm{Ng} 2$-Cre line (Kunisaki et al. 2013; Asada et al. 2017a) and represent a major HSC regulatory component within the niche. Depletion of these cells (using the Ng2$C r e^{E R T M} /$ iDTR model) significantly impaired HSC quiescence, leading to exhaustion of HSCs (Kunisaki et al. 2013), and Scf depletion in NG2targeted cells (using the $\mathrm{Ng} 2-\mathrm{Cre} / \mathrm{Scflox} /-$ model) reduced HSC numbers in the BM and compromised their long-term reconstitution activity (Asada et al. 2017a). Several other candidate perivascular stromal cells have also been suggested to regulate healthy HSCs, including CAR cells (Sugiyama et al. 2006), Lepr-expressing cells (Ding et al. 2012), and stromal cells targeted by either Osx-Cre or paired related homeobox-1 (Prx-1)-Cre (Ding and Morrison 2013; Greenbaum et al. 2013); however, these cell types were shown to largely overlap with Nestin-green fluorescent protein-positive $\left(\mathrm{GFP}^{+}\right)$MSCs (Kunisaki et al. 2013; Pinho et al. 2013; Asada et al. 2017a).

Like more mature osteolineage cells, Nestin$\mathrm{GFP}^{+}$MSCs express $\beta$-ARs. However, in contrast to osteoblasts in which stimulation of $\beta 2$ ARs controls bone remodeling (Takeda et al. 2002), signaling via the $\beta 3$-ARs on MSCs was shown to be critical for their homeostasis (Mendez-Ferrer et al. 2008, 2010a). Denervation studies showed that ablation of SNS signals leads to proliferation and expansion of normally quiescent MSCs, whereas adrenergic stimulation, mediated through $\beta 3$-ARs, leads to decreased osteogenic differentiation and expression of HSC-regulating genes (Mendez-Ferrer et al. 2010b; Lucas et al. 2013). Thus, similar to osteoblasts and osteocytes abundant in the compact bone (Takeda et al. 2002; Elefteriou et al. 2005; Asada et al. 2013), BM-derived MSCs are a major target of the SNS.

Additional neural crest derivatives have also been identified in the HSC niche. Nonmyelinating Schwann cells that wrap around sympathetic nerve fibers were suggested to preserve HSC quiescence through activation of transforming growth factor $\beta$ (TGF- $\beta$ ) and SMAD signaling (Yamazaki et al. 2011). In this study, denervation of sympathetic nerves resulted in significant decrease in Schwann cell numbers, which com- promised HSC dormancy and induced HSC loss as early as 3 days after denervation surgery. However, in another study, acute surgical and chemical sympathectomy did not alter HSC and progenitor numbers in the BM (MendezFerrer et al. 2008). Thus, it remains unclear how sympathetic nerves can signal to Schwann cells and to what extent BM denervation, independent from off-target effects such as inflammation following surgery, contributed to the effects observed on HSCs. Other neurotrophic factors and neuropeptides may also regulate HSC homeostasis (Liu et al. 2007). For instance, release from NPY by SNS nerves was shown to enhance the activity of matrix metalloproteinase- 9 in the BM microenvironment, leading to degradation of HSC and progenitor retention factors, resulting in HSC mobilization (Park et al. 2015, 2016). Moreover, SP and neurokinin-A, members of the tachykinin family of neuropeptides, have been suggested to stimulate production of hematopoietic cytokines by BM stromal cells, in addition to serving as essential modulators of both normal and malignant hematopoiesis (Nowicki et al. 2007).

\section{Sympathetic Control of Healthy Hematopoiesis}

Initial evidence that SNS nerves might regulate hematopoiesis emerged from studies describing a positive correlation between BM circadian oscillations of NE and proliferation of hematopoietic cells (Maestroni et al. 1998). The finding that fucoidan, a selectin glycomimetic inhibitor, induced rapid HSC mobilization, independent of selectin inhibition (Frenette 2000; Sweeney et al. 2000), raised the possibility that sulfated glycans in the BM microenvironment modulate HSC retention. Indeed, mice deficient in the uridine diphosphate (UDP)-galactose ceramide galactosyltransferase $\left(\mathrm{Cgt}^{-/-}\right)$, an enzyme that catalyzes the final step of galactocerebroside (GalC) synthesis, the major component of myelin sheaths and responsible for adequate nerve conduction (Norton and Cammer 1984), showed poor mobilization of HSCs when stimulated with granulocyte colony-stimulating factor (G-CSF) (Katayama et al. 2006). 
M. Maryanovich et al.

HSC and progenitor mobilization from the $\mathrm{BM}$ to peripheral organs depends on an intact gradient of the CXCL12 chemokine, which can be disrupted following administration of G-CSF, leading to rapid HSC and progenitor egress from the BM (Hattori et al. 2001; Petit et al. 2002). Local sympathetic nerves deliver, in a circadian manner, SNS signals to the BM, which are transduced by $\beta$-ARs, leading to down-regulation of CXCL12 expression and rhythmic release of HSCs (Mendez-Ferrer et al. 2008). Sympathetic denervation in genetic and pharmacological models blunts the CXCL12 down-regulation after G-CSF treatment, resulting in impaired hematopoietic stem and progenitor cell (HSPC) mobilization (Katayama et al. 2006; MendezFerrer et al. 2008, 2010a). Nevertheless, the defective HSPC mobilization in $\mathrm{Cgt}^{-1-}$ mice was not caused by the lack of GalC production but rather impaired adrenergic regulation of niche cells involved in the mobilization of HSCs (Katayama et al. 2006). Additional studies of leukocyte and stem cell recruitment to the BM showed that circadian oscillations in endothelial adhesion molecules depended on expression of $\beta$-ARs and require local delivery of NE (Scheiermann et al. 2012). These seminal studies propose a model in which core genes of the molecular clock in the CNS act through local circadian NE secretion to regulate HSC retention, mobilization, and homing.

CXCL12 is largely secreted by perivascular MSCs, and to lesser extent by endothelial cells and osteoblasts (Ding and Morrison 2013; Greenbaum et al. 2013; Asada et al. 2017a). The circadian release of HSCs is mediated by $\beta 3$-ARs that are predominantly expressed by Nestin-GFP ${ }^{+}$MSCs (Mendez-Ferrer et al. 2010b). However, G-CSF-enforced mobilization of HSPCs depends on adrenergic signals mediated through both $\beta 2$ and $\beta 3$-ARs (Mendez-Ferrer et al. 2010a), associated with suppression of MSC and osteolineage cell function (Semerad et al. 2005; Katayama et al. 2006; Christopher and Link 2008; Mendez-Ferrer et al. 2008, 2010a; Asada et al. 2013). It is important to note that G-CSF-mediated mobilization not only down-regulates CXCL12 production by Nestin-GFP ${ }^{+}$MSCs but also suppresses the function of macrophages, which was shown to affect HSC mobilization (Semerad et al. 2005; Chow et al. 2011). Therefore, enforced mobilization is a complex process involving cross talk between several different cell types in the BM microenvironment.

Besides HSC mobilization, SNS signals are essential for regeneration of hematopoiesis following genotoxic stress (Lucas et al. 2013). Exposure to neurotoxic drugs (e.g., chemotherapy or exposure to irradiation) damages the $\mathrm{BM}$ microenvironment leading to sympathetic neuropathy and induction of MSC and endothelial cell proliferation. Excess proliferation further sensitizes these cells to genotoxic insults, leading to reduced niche size and failure to support hematopoietic recovery. Administering of the neuroprotective agents 4-methylcatechol (4-MC) or the glial-derived neurotrophic factor (GDNF) together with the neurotoxic agents rescued sympathetic nerve fibers (Lucas et al. 2013). This combined treatment protected BM niche cells from genotoxic insults and allowed normal hematopoietic recovery. These studies thus suggest that diseases or therapies accompanied with peripheral neuropathy have an underappreciated long-term damaging effect on hematopoiesis, which is preventable.

Despite the essential role of the SNS in regulating the HSC niche, one must also consider a direct effect on hematopoietic cells. Expression of ARs on HSCs and progenitors was documented in both human and rodent, with HSCs mainly expressing the $\alpha 1, \alpha 2$, and $\beta 2$-ARs but not $\beta 3$-ARs (Muthu et al. 2007). Interestingly, however, the function of AR stimulation on HSCs still remains poorly understood. Human hematopoietic progenitors were shown to be regulated directly by SNS signals, as immature clusters of differentiation 34-positive $\left(\mathrm{CD} 34^{+}\right)$ progenitors express dopamine receptors, which can be induced following G-CSF mobilization (Spiegel et al. 2007). Furthermore, catecholamines support both motility and proliferation of $\mathrm{CD} 34^{+}$progenitors, which suggests that the SNS has both HSC autonomous and nonautonomous (niche-mediated) effects. Similar to rodents, mobilized human stem and progenitor cells also fluctuate in a circadian manner, al- 
though the circadian rhythm in humans is inverted with significantly higher yields of stem cells toward the evening (Lucas et al. 2008). This might be clinically relevant for mobilization and BM transplantation when treating malignant blood disorders (Gratwohl et al. 2013).

\section{Role of SNS Nerves in the Progression of Hematological Malignancies}

In line with the findings of neuronal regulation of normal hematopoiesis as described earlier, recent studies show that neuropathy in the SNS is involved in the development of hematological malignancies. It is becoming increasingly clear that at least in some malignancies including leukemia, cancer progression displays features similar to normal tissue organization. That is, there may be a developmental hierarchy in cells that constitute cancer in which cancer stem cells (CSCs) have a potential to self-renew and give rise to transient-amplifying cancer cells that are driving tumor growth (Clevers 2011; Kreso and Dick 2014). The origin of CSCs is still controversial, and one of the proposed hypotheses is that CSCs emerge as a result of accumulation of mutations in stem cells (or other longlived cells) in the tissue (Passegue et al. 2003; Bjerkvig et al. 2005). Consistent with this notion, CSCs are known to share many biological characteristics with their healthy counterparts, including maintenance of quiescence in the cell cycle (Pece et al. 2010; Roesch et al. 2010; Saito et al. 2010). Given that it is considered that such properties render CSCs resistant to currently available anticancer drugs that preferentially target dividing cells and that residual CSCs after therapies are a potential cause of relapse (Clevers 2011; Kreso and Dick 2014), research aiming to comprehend CSC behavior has drawn more attention in the field of cancer biology, and therapies that are able to eradicate CSCs are now being intensely developed.

Leukemia stem cells (LSCs), the CSCs of leukemia, have contributed to our knowledge just as HSCs have long served as an important experimental subject to dissect mechanisms by which healthy stem cell function is regulated. Previous studies with the use of the xenograft model of
LSCs in human primary acute myelogenous leukemia (AML) showed that leukemic cells reside in the endosteal region of the BM after treatment with the antileukemic agent cytosine arabinoside (Ara-C) (Ishikawa et al. 2007), and these residual cells were found to be quiescent (Saito et al. 2010). Although the detailed localization of LSCs in the BM still remains to be solved, given the clinical finding that patients with hematological malignancies are likely to show pancytopenia (a reduction in the number of red and white blood cells as well as platelets), it has been postulated that HSCs are expelled from their niche in these diseases and LSCs use the resultant vacant area for leukemogenesis. Another evidence that leukemia patients who have received allogeneic stem cell transplantation can develop donor-derived leukemia (Wiseman 2011) further suggests that LSCs might not only occupy the HSC niche but also remodel it into a malignant microenvironment. Indeed, there are several studies showing morphological and functional alterations of BM stromal cells in patients with various hematological diseases, including AML, myelodysplastic syndrome (Duhrsen and Hossfeld 1996), and primary myelofibrosis (Pereira et al. 1990).

Owing to recent advances in generation of murine models of hematological diseases, mechanistic insights into the formation and function of malignant niches have been provided. For instance, a mouse model of chronic myelogenous leukemia (CML), which is caused by a chromosomal translocation that joins the $B C R$ and $A B L$ genes (Rowley 1973; de Klein et al. 1982), was established by generation of inducible BCR-ABL transgenic mice (Reynaud et al. 2011). In this model, leukemia cells induced MSCs to expand their osteolineage cells, and such MSC stimulation required direct contact of leukemic cells (Fig. 4A) (Schepers et al. 2013). These interactions led to the overproduction of C-C motif ligand 3 (CCL3) and thrombopoietin (TPO) and alteration of several signaling pathways, including TGF- $\beta$, Notch, and Wnt. The remodeled osteolineage cells showed impaired capacity to support HSCs while LSCs were maintained in such an environment, indicating that leukemic cells indeed remodel the 
M. Maryanovich et al.



Figure 4. Altered hematopoietic stem cell (HSC) niche, including sympathetic neuropathy, promotes progression of hematological malignancies. $(A)$ In a mouse model of chronic myelogenous leukemia (CML), BCR-ABL ${ }^{+}$ leukemic cells produce cytokines, including $\mathrm{C}-\mathrm{C}$ motif ligand 3 (CCL3) and thrombopoietin (TPO), and mesenchymal stem cells (MSCs) show skewed differentiation toward osteolineage cells. HSC maintenance factors such as SCF and CXCL12 are down-regulated in these remodeled MSCs, leading to impaired hematopoiesis. Imatinib treatment partially corrects the alteration of HSC maintenance factor expression in MSCs. (B) In an acute myelogenous leukemia (AML) mouse model transduced with mixed lineage leukemia AF9 (MLL-AF9) retrovirus, catecholaminergic fibers around arterioles are degenerated. Neuropathy is accompanied by expanded $\beta 2$-adrenergic receptor (AR)-expressing MSCs that are directed toward the osteoblastic cells. Similar to the CML mouse model, the expression of HSC maintenance factors is decreased in MSCs and normal hematopoiesis is compromised. $(C)$ In a myeloproliferative neoplasm (MPN) mouse model harboring human Janus kinase 2 (JAK2[V617F]) transgene, mutant hematopoietic stem and progenitor cells (HSPCs) secrete interleukin $1 \beta$ (IL$1 \beta$ ) that damages sympathetic nervous system (SNS) fibers and Schwann cells. In contrast to AML mice, neuropathy results in apoptosis of $\beta 3$-AR-expressing MSCs and a reduction of these cells. 
HSC niche into a self-reinforcing malignant microenvironment at the expense of normal hematopoiesis. Another study showed that expressions of cytokines, including CXCL12 and IL- $1 \alpha$, were also altered in the BM of CML patients, some of which were partially corrected after the complete cytogenetic remission (no detection of BCR-ABL ${ }^{+}$cells by fluorescence in situ hybridization) was obtained by the treatment of BCR-ABL inhibitor imatinib mesylate (IM) (Fig. 4A) (Zhang et al. 2012).

In the case of AML, it has been recently reported that this disease disrupted catecholaminergic fibers around arterioles in a murine model generated by retroviral infection of HSPCs with MLL-AF9 (Hanoun et al. 2014). In line with this finding, the treatment of these mice with 6hydroxydopamine, which specifically damages catecholaminergic neurons (Katayama et al. 2006; Mendez-Ferrer et al. 2008), increased phenotypic LSCs. Neuropathy was accompanied by activation of the cell cycle in phenotypic MSCs and endothelial cells, leading to expansion of these cells. Similar to the finding in the CML mouse model, these expanded MSCs were directed toward the osteoblastic lineage (Fig. 4B). In addition, the frequency of $\mathrm{NG}^{+}$periarteriolar cells was reduced and the expression of HSC maintenance factors such as CXCL12 and SCF was decreased in MSCs, which underlies the compromised hematopoiesis in AML. Consistent with previous studies showing that signaling through $\beta 2-\mathrm{AR}$ and $\beta 3-\mathrm{AR}$ plays a role in bone formation (Takeda et al. 2002; Elefteriou et al. 2005) and HSC niche maintenance (Mendez-Ferrer et al. 2008), respectively, the expression of $\beta 3$-ARs was reduced in MSCs of AML mice compared with healthy animals, whereas $\beta 2$-AR levels were equivalent between these groups. Furthermore, the $\beta 2-\mathrm{AR}$ antagonist, but not the $\beta 3-\mathrm{AR}$ antagonist, increased the number of LSCs in the BM and augmented colony-forming capacity of leukemic cells, leading to shorten survival of AML mice. Although $\beta 2$ ARs were also expressed in leukemic cells, transplantation experiments of wild-type leukemic cells into $\beta 2$-AR-deficient or -sufficient mice revealed a higher BM infiltration of leukemic cells in the former mice, suggesting a critical role for $\beta 2$-ARs expressed in the microenvironment Conversely, the administration of $\beta 2$-AR agonist resulted in a decrease of LSCs in the BM, providing further evidence that neuropathy in the SNS is essential for LSC maintenance and disease progression in AML through down-regulation of $\beta 2$-AR signaling in the malignant niche. It is notable that $\beta 2$-AR agonist was also shown to have a potential to enhance proliferation of leukemic cells in a cell-autonomous manner, suggesting that the SNS neuropathy affects LSCs and their niche differently. In the same mouse model, another study showed that Bmal1-deficient LSCs showed the compromised potential to evoke the disease in the wild-type microenvironment, indicating that the circadian rhythm in leukemic cells is essential for AML development (Puram et al. 2016). Although the precise mechanism underlying this phenotype remains elusive, this study again raises the possibility of the differential role of the SNS in the maintenance of LSCs and their microenvironment. In addition to involvement of the SNS, it was recently reported that vascular permeability in the BM is increased in AML and inhibition of endothelial cell-derived nitric oxide is able to normalize the vasculature and improve response to Ara-C (Passaro et al. 2017).

Most patients with myeloproliferative neoplasm (MPN) who do not carry the $B C R-A B L$ fusion gene have an acquired mutation in Janus kinase 2 (JAK2[V617F]) in HSCs, conferring constitutive kinase activity to this molecule (Baxter et al. 2005; Kralovics et al. 2005), and mice harboring such mutated human JAK2 transgenes show phenotypes that resemble MPN (Tiedt et al. 2008). With the use of this model, it was shown that the density of Schwann cells and SNS fibers in the BM were reduced in MPN, which was triggered by mutant HSPCproducing IL-1 $\beta$ (Fig. 4C) (Arranz et al. 2014). In contrast to the finding in AML mice, neuropathy in MPN led to apoptosis of MSCs and a reduction of these cells. Neuroprotective manipulation with 4-MC treatment rescued Schwann cells and prevented neutrophilia (an increase of neutrophils in the peripheral blood, which is one of the hematological abnormalities in MPN). Similarly, the treatment with $\beta 3-\mathrm{AR}$ agonist 
M. Maryanovich et al.

led to recovery of the number of MSCs and a decrease of mutant HSCs that prevented MPN progression, indicating that alteration of signaling through $\beta 3$-ARs plays a role in the pathogenesis of MPN unlike AML. Collectively, hematological malignancies induce alterations in HSC microenvironment in the BM, including neuropathy, which are essential for disease progression.

\section{NEURONAL REGULATION OF IMMUNE FUNCTION}

It was during the ancient Roman period that dolor (pain) was originally depicted as a cardinal sign of inflammation, and this long-known fact implies the interaction of the immune system with the nervous system. Such interplay appears to be ideal for immediate pathogen clearance, considering that the nervous system is able to react rapidly to stimuli. Several immune cell types express receptors for neurotransmitters, and these transmitters and immune mediators use the same secondary signaling pathways such as cAMP. Indeed, it was shown that inflammatory signals can activate sensory nerves during an immune response, leading to the secretion of several neuropeptides (Fig. 5A) (Deutschman and Tracey 2014). For instance, some cytokines can induce production of SP and CGRP, which are released from sensory nerve endings and transmits pain information to the CNS (De Felipe et al. 1998; Schafers et al. 2003). These neuropeptides also act as a vasodilator (Brain et al. 1985; Bossaller et al. 1992) and facilitate inflammation by enhancing blood flow, vascular leakiness, and leukocyte trafficking to sites of infection, which evokes calor (heat), rubor (redness), and tumor (swelling), the other classical signs of inflammation. In line with these findings, the administration of antagonists to these neuropeptides and the severance of peripheral nerves were shown to attenuate inflammation (Green et al. 1993). On the contrary, a recent study has reported that activation of the sensory sciatic nerve by electroacupuncture led to dampened inflammation in an experimental sepsis model through dopamine production in the adrenal glands (Torres-Rosas et al. 2014), suggesting that sensory nerves can also function as an anti-inflammatory mechanism.

The facts that infection causes fever and the body temperature is regulated primarily by the hypothalamus point to a link between CNS area and the immune system. Previous studies have shown that signals through afferent nerves and inflammatory mediators activate the HPA axis, leading to the secretion of glucocorticoids from the adrenal cortex (Sternberg 2006). Glucocorticoids act to suppress proliferation and differentiation of many types of immune cells, including macrophages and dendritic cells (Matyszak et al. 2000; Woltman et al. 2002). Furthermore, glucocorticoids tend to prevent trafficking of these cells from immune organs to sites of inflammation through suppression of the expression of cell-adhesion molecules and chemokines (Fig. 5B) (Cronstein et al. 1992; Miyamasu et al. 1998). Consistent with these findings that the HPA axis provides a negative feedback loop of inflammation, deregulation of this axis is observed in patients with a wide range of autoimmune diseases such as rheumatoid arthritis (RA) and systemic lupus erythematosus (Sternberg 2006). In addition, glucocorticoid resistance attributable to mutations of glucocorticoid receptors is also seen in these diseases (Derijk et al. 2001; Lee et al. 2004). Conversely, an elevation of circulating glucocorticoids, which can result from chronic stress, was found to be associated with increased susceptibility to viral infections and decreased antibody production after vaccination (Vedhara et al. 1999; Glaser and Kiecolt-Glaser 2005). Collectively, the HPA axis fine-tunes immune homeostasis to avoid both prolonged proinflammatory responses and excessive immunosuppression.

Although the SNS innervates primary and secondary lymphoid organs and provides signals in inflammation, the description in the literature is complex and it appears that this system has varying effects over the time course of an immune response; the SNS is proinflammatory in the early stage of a mouse model of arthritis, whereas adrenergic signals have an anti-inflammatory impact at the later stage (Fig. 5C) (Harle et al. 2005). Such observations might be attributable in part to the fact that NE 
A

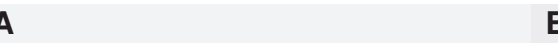

Sensory nerve

B

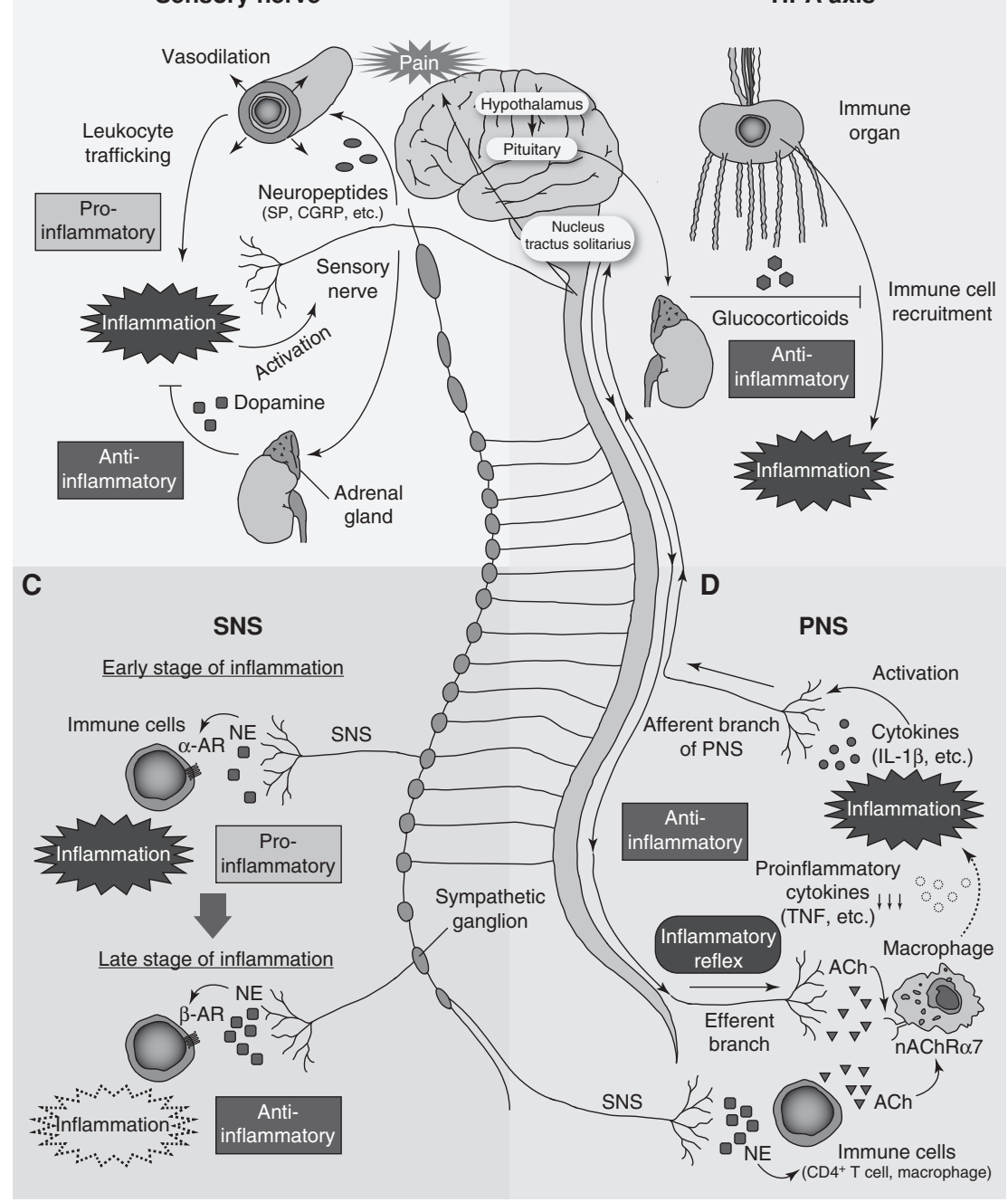

Figure 5. The nervous system fine-tunes the inflammatory responses and maintains the immune homeostasis. $(A)$ Sensory nerves are activated by inflammatory signals, leading to the secretion of neuropeptides such as substance $\mathrm{P}(\mathrm{SP})$ and calcitonin gene-related peptide (CGRP) from nerve endings. These substances induce proinflammatory responses through several processes, including enhancing blood flow and trafficking leukocytes to inflammation sites. Activated sensory nerves also transmit pain information to the central nervous system (CNS). On the other hand, sensory nerves can evoke anti-inflammatory responses through dopamine production in the adrenal glands. (B) Activation of hypothalamic-pituitary-adrenal (HPA) axis by inflammatory mediators leads to the glucocorticoid secretion from the adrenal cortex. This hormone prevents trafficking of immune cells from immune organs to inflammation sites, acting as an anti-inflammatory mechanism. (C) The sympathetic nervous system (SNS) is proinflammatory in the early stage of inflammation, which might be attributable in part to the fact that norepinephrine (NE) promotes inflammation through $\alpha$-adrenergic receptors (ARs) at low concentrations. In contrast, high concentrations of NE suppress inflammation through $\beta$-ARs, which could underlie the observation that adrenergic signals have an anti-inflammatory impact at the later stage of inflammation. $(D)$ Afferent branches of the parasympathetic nervous system (PNS) are activated by cytokines, including interleukin (IL)-1 $\beta$ from inflammation sites and signals are sent to the nucleus tractus solitarius (the parasympathetic brain region). This, in turn, activates efferent branches of the PNS, referred to as "inflammatory reflex." Signals through the $\mathrm{nAChR} \alpha 7$ subunit of macrophages inhibit the production of proinflammatory cytokines such as tumor necrosis factor (TNF) in these cells, rendering the PNS an anti-inflammatory mechanism. The origin of acetylcholine (ACh) that acts on macrophages is controversial and among the candidates are the efferent branches of the PNS and immune cells, including $\mathrm{CD} 4^{+} \mathrm{T}$ cells and macrophages that are triggered by NE from the SNS. 
M. Maryanovich et al.

has proinflammatory effects through $\alpha$-ARs at low concentrations, whereas it has predominantly anti-inflammatory effects through $\beta$ ARs at high concentrations (Pongratz and Straub 2013). These studies indicate that the SNS acts initially to amplify immune responses to clear pathogens and, subsequently, it may counterbalance to terminate inflammation. In line with these findings, a clinical study suggested that the level of $\beta 2$-AR expression in mononuclear cells is lower in RA patients than in healthy donors (Baerwald et al. 1992). In addition, in active juvenile RA, leukocytes have a lower cAMP response to $\beta 2-\mathrm{AR}$ agonist (Kuis et al. 1996), indicating that AR expression pattern in immune cells as well as neuroimmune response are altered in autoimmune diseases. Such SNS-mediated modulation of the immune system is influenced by the circadian rhythm (Scheiermann et al. 2012). This study showed that leukocytes were recruited to tissues, including the BM, in a circadian rhythm-dependent manner peaking at night, and conversely the number of leukocytes in the peripheral blood increased during the day as was observed for HSCs (Mendez-Ferrer et al. 2008). Surgical ablation of the SNS abolished such oscillation, emphasizing the role of the SNS in the circadian rhythm-dependent leukocyte trafficking. Furthermore, mouse survival deteriorated when sepsis was induced in the night compared with the morning, suggesting that a circadian rhythm in leukocyte recruitment can affect the outcome of inflammation. Consistent with the fact that rodents and humans display opposite circadian rhythms, the number of leukocytes in the circulation decreases during the night in humans (Haus and Smolensky 1999). It is possible that the leukocyte recruitment in tissues peaks during the day in humans, and this might explain in part the mechanism underlying symptoms of several chronic diseases that show circadian exacerbations (Scheiermann et al. 2013), such as joint stiffness in RA patients, which is typically experienced in the early morning (Cutolo 2012).

The PNS also senses inflammation and modulates immune responses. Previous studies have shown that IL-1 $\beta$ released from activated immune cells binds to its receptor on parasym- pathetic ganglia and sends signals to afferent fibers of the vagus nerve and subsequently parasympathetic brain regions (Fig. 5D) (Goehler et al. 2000). This leads to activation of efferent vagus nerve fibers, which induces release of $\mathrm{ACh}$ from this branch. Although both nAChRs and mAChRs are found in immune cells, nAChRs specifically mediate cholinergic signals. Activation of the nAChR $\alpha 7$ subunit was shown to exhibit anti-inflammatory effects by inhibiting proinflammatory cytokine production (Borovikova et al. 2000; Wang et al. 2003) and by suppressing the expression of endothelial cell-adhesion molecules (Saeed et al. 2005), and thus the PNS counteracts the systemic inflammatory responses. However, unlike the SNS, there is no definite evidence for parasympathetic innervation of the immune system (Schafer et al. 1998; Nance and Sanders 2007). It is notable that the anti-inflammatory effect of vagus nerve stimulation requires a $\beta 2-\mathrm{AR}$ on $\mathrm{CD} 4^{+} \mathrm{CD} 25^{-}$lymphocytes (Vida et al. 2011), indicating that this stimulation uses sympathetic nerve relay.

In summary, the interplay between the neural system and the immune system allows the host to enhance inflammatory responses to promptly clear pathogens as well as to terminate inflammation and return the host to a resting state after elimination of pathogens. This finetuned mechanism plays a pivotal role in the maintenance of immune homeostasis with deregulation of such a system being associated with autoimmune diseases.

\section{CONCLUDING REMARKS}

Although enormous progress has been made in elucidating neuronal regulation of bone and BM, there are several important unanswered questions. For instance, it remains unexplored whether and how such regulation alters with aging. It is known that bone remodeling and hematopoiesis undergo functional changes with aging, and the elderly are more likely to experience osteoporosis and hematological abnormalities. In the case of hematopoiesis, previous studies have shown that the number of phenotypic HSCs increases accompanied by disrupted cell cycle and biased differentiation toward the myeloid lineage and 
compromised BM reconstitution potential (Mendelson and Frenette 2014; Oh et al. 2014). In addition, it was reported that the HSC microenvironment was also altered in old mice, including the decrease in the number of mesenchymal progenitor cells located near the endosteal surface (Siclari et al. 2013) and the decline of vasculature (Kusumbe et al. 2016). However, it is currently unknown whether deregulation of the nervous system is involved in these phenotypes.

Another important point is whether targeting the nervous system indeed becomes a new therapy for hematological malignancies. As introduced in this review, there are two strategies adopted so far to alter the neuronal regulation: (1) targeting ARs, and (2) modulating the circadian rhythm. Regarding the former approach, although $\beta 2$-AR agonist is broadly used for the treatment of bronchial asthma, its application to AML patients warrants careful consideration, given the potential of this drug to promote proliferation of leukemic cells in a cell-autonomous manner (Hanoun et al. 2014). $\beta 3$-AR agonist appears promising for the MPN treatment, but the direct effect of this drug on leukemic cells was not investigated. Fortunately, $\beta 3$-AR agonist BRL37344 did not affect blood counts in wildtype mice (Arranz et al. 2014), and the effect of this agent on human HSCs also needs to be carefully monitored in a clinical trial. Regarding the latter approach, there are currently no FDAapproved drugs that are able to directly target Bmal1. Ramelteon, which modulates circadian rhythm by binding to melatonin receptors on the suprachiasmatic nucleus (a brain region controlling circadian rhythm), is now used for the treatment of insomnia (Brasure et al. 2015), and it will be intriguing to test the effect of such drugs on leukemia progression.

The finding that characteristics of BM stromal cells in the CML mouse model were not completely reverted by imatinib administration (Zhang et al. 2012) points out one critical issue about currently performed therapies. Anti-leukemic agents, including molecular-targeted drugs, have been developed to damage leukemic cells, and it is known that patients experience relapse after discontinuation of therapies in most cases. There are many proposed explana- tions for such unfavorable outcomes, and the finding in the IM-treated CML mice implies the possibility that alterations in the microenvironment that persist after therapies potentially initiate and/or sustain leukemia. Together with evidence that stromal cell populations isolated from individuals with myeloid malignancies can harbor genetic abnormalities that are different from mutations in leukemic clones (Blau et al. 2007), agents that target leukemic cells should be combined with approaches to modulate malignant microenvironments. Indeed, it was recently reported that a combination of IL-1 receptor antagonist with another BCR-ABL inhibitor nilotinib ameliorated the survival of CML mice compared with nilotinib treatment alone (Zhang et al. 2016). Combination with anti-leukemic cell drugs is also expected to mitigate the effect of $\beta 2$-AR agonist on proliferation of leukemic cells. Another important question is whether the strategy to target the nervous system is expandable to other types of cancer. Given that growth of prostate cancer cells was inhibited when these cells were orthotopically transplanted into $\beta 2-A R$ and $\beta 3$-AR-deficient mice (Magnon et al. 2013), modulation of activity of the nervous system may be a promising approach against a broad spectrum of cancers.

\section{ACKNOWLEDGMENTS}

Work in the Frenette laboratory is supported by the National Institutes of Health (NIH) (DK056638, HL116340, HL097819) and the Leukemia and Lymphoma Society (LLS) Translational Research Program. M.M. is a New York Stem Cell Foundation (NYSCF) Druckenmiller Fellow and was previously supported by the EMBO European Commission FP7 (Marie Curie Actions; EMBOCOFUND2012, GA-2012600394, ALTF 447-2014). S.T. is supported by the Japan Society for the Promotion of Science (JSPS) Postdoctoral Fellowships for Research Abroad.

\section{REFERENCES}

Acar M, Kocherlakota KS, Murphy MM, Peyer JG, Oguro H, Inra CN, Jaiyeola C, Zhao Z, Luby-Phelps K, Morrison SJ. 
M. Maryanovich et al.

2015. Deep imaging of bone marrow shows non-dividing stem cells are mainly perisinusoidal. Nature 526: $126-$ 130.

Alenina N, Klempin F. 2015. The role of serotonin in adult hippocampal neurogenesis. Behav Brain Res 277: 49-57.

Arai F, Hirao A, Ohmura M, Sato H, Matsuoka S, Takubo K, Ito K, Koh GY, Suda T. 2004. Tie2/angiopoietin-1 signaling regulates hematopoietic stem cell quiescence in the bone marrow niche. Cell 118: 149-161.

Arranz L, Sanchez-Aguilera A, Martin-Perez D, Isern J, Langa X, Tzankov A, Lundberg P, Muntion S, Tzeng YS, Lai DM, et al. 2014. Neuropathy of haematopoietic stem cell niche is essential for myeloproliferative neoplasms. Nature 512: 78-81.

Artico M, Bosco S, Cavallotti C, Agostinelli E, Giuliani-Piccari G, Sciorio S, Cocco L, Vitale M. 2002. Noradrenergic and cholinergic innervation of the bone marrow. International J Mol Med 10: 77-80.

Asada N, Katayama Y, Sato M, Minagawa K, Wakahashi K, Kawano H, Kawano Y, Sada A, Ikeda K, Matsui T, et al. 2013. Matrix-embedded osteocytes regulate mobilization of hematopoietic stem/progenitor cells. Cell Stem Cell 12: 737-747.

Asada N, Kunisaki Y, Pierce H, Wang Z, Fernandez NF, Birbrair A, Maayan A, Frenette PS. 2017a. Differential cytokine contributions of perivascular haematopoietic stem cell niches. Nat Cell Biol 19: 214-223.

Asada N, Takeishi S, Frenette PS. 2017b. Complexity of bone marrow hematopoietic stem cell niche. Int J Hematol 106: 45-54.

Baerwald C, Graefe C, Muhl C, Von Wichert P, Krause A. 1992. $\beta 2$-adrenergic receptors on peripheral blood mononuclear cells in patients with rheumatic diseases. Eur $J$ Clin Invest 22: 42-46.

Bajayo A, Bar A, Denes A, Bachar M, Kram V, Attar-Namdar M, Zallone A, Kovács KJ, Yirmiya R, Bab I. 2012. Skeletal parasympathetic innervation communicates central IL-1 signals regulating bone mass accrual. Proc Natl Acad Sci 109: $15455-15460$.

Baldock PA, Sainsbury A, Couzens M, Enriquez RF, Thomas GP, Gardiner EM, Herzog H. 2002. Hypothalamic Y2 receptors regulate bone formation. J Clin Invest 109: 915-921.

Baldock PA, Sainsbury A, Allison S, Lin EJD, Couzens M, Boey D, Enriquez R, During M, Herzog H, Gardiner EM. 2005. Hypothalamic control of bone formation: Distinct actions of leptin and Y2 receptor pathways. J Bone Miner Res 20: 1851-1857.

Baldock PA, Allison SJ, Lundberg P, Lee NJ, Slack K, Lin EJD, Enriquez RF, McDonald MM, Zhang L, During MJ, et al. 2007. Novel role of Y1 receptors in the coordinated regulation of bone and energy homeostasis. J Biol Chem 282: 19092-19102.

Baldock PA, Lee NJ, Driessler F, Lin S, Allison S, Stehrer B, Lin EJD, Zhang L, Enriquez RF, Wong IPL, et al. 2009. Neuropeptide Y knockout mice reveal a central role of NPY in the coordination of bone mass to body weight. PLos ONE 4: e8415.

Baron R, Rawadi G. 2007. Targeting the Wnt $/ \beta$-catenin pathway to regulate bone formation in the adult skeleton. Endocrinology 148: 2635-2643.
Baxter EJ, Scott LM, Campbell PJ, East C, Fourouclas N, Swanton S, Vassiliou GS, Bench AJ, Boyd EM, Curtin $\mathrm{N}$, et al. 2005. Acquired mutation of the tyrosine kinase JAK2 in human myeloproliferative disorders. Lancet 365: 1054-1061.

Bellinger DL, Lorton D, Felten SY, Felten DL. 1992. Innervation of lymphoid organs and implications in development, aging, and autoimmunity. Int I Immunopharmacol 14: $329-344$

Berendsen AD, Olsen BR. 2015. Bone development. Bone 80: $14-18$.

Bjerkvig R, Tysnes BB, Aboody KS, Najbauer J, Terzis AJ. 2005. Opinion: The origin of the cancer stem cell: Current controversies and new insights. Nat Rev Cancer 5: 899904.

Bjurholm A, Kreicbergs A, Brodin E, Schultzberg M. 1988a. Substance P- and CGRP-immunoreactive nerves in bone. Peptides 9: 165-171.

Bjurholm A, Kreicbergs A, Terenius L, Goldstein M, Schultzberg M. 1988b. Neuropeptide Y-, tyrosine hydroxylaseand vasoactive intestinal polypeptide-immunoreactive nerves in bone and surrounding tissues. J Auton Nerv Syst 25: 119-125.

Blau O, Hofmann WK, Baldus CD, Thiel G, Serbent V, Schumann E, Thiel E, Blau IW. 2007. Chromosomal aberrations in bone marrow mesenchymal stroma cells from patients with myelodysplastic syndrome and acute myeloblastic leukemia. Exp Hematol 35: 221-229.

Bonnet N, Benhamou CL, Malaval L, Goncalves C, Vico L, Eder V, Pichon C, Courteix D. 2008. Low dose $\beta$-blocker prevents ovariectomy-induced bone loss in rats without affecting heart functions. J Cell Physiol 217: 819-827.

Borovikova LV, Ivanova S, Zhang M, Yang H, Botchkina GI, Watkins LR, Wang H, Abumrad N, Eaton JW, Tracey KJ. 2000. Vagus nerve stimulation attenuates the systemic inflammatory response to endotoxin. Nature 405: 458462.

Bossaller C, Reither K, Hehlert-Friedrich C, Auch-Schwelk W, Graf K, Grafe M, Fleck E. 1992. In vivo measurement of endothelium-dependent vasodilation with substance $\mathrm{P}$ in man. Herz 17: 284-290.

Boyden LM, Mao J, Belsky J, Mitzner L, Farhi A, Mitnick MA, Wu D, Insogna K, Lifton RP. 2002. High bone density due to a mutation in LDL-receptor-related protein 5 . N Engl J Med 346: 1513-1521.

Brain SD, Williams TJ, Tippins JR, Morris HR, MacIntyre I. 1985. Calcitonin gene-related peptide is a potent vasodilator. Nature 313: 54-56.

Brasure M, MacDonald R, Fuchs E, Olson CM, Carlyle M, Diem S, Koffel E, Khawaja IS, Ouellette J, Butler M, et al. 2015. Management of insomnia disorder. Agency for Healthcare Research and Quality, Rockville, MD.

Broome CS, Miyan JA. 2000. Neuropeptide control of bone marrow neutrophil production: A key axis for neuroimmunomodulation. Ann NY Acad Sci 917: 424-434.

Calvi LM, Adams GB, Weibrecht KW, Weber JM, Olson DP, Knight MC, Martin RP, Schipani E, Divieti P, Bringhurst FR, et al. 2003. Osteoblastic cells regulate the haematopoietic stem cell niche. Nature 425: 841-846.

Calvo W. 1968. The innervation of the bone marrow in laboratory animals. Am J Anat 123: 315-328. 
Canalis E, Delany AM. 2002. Mechanisms of glucocorticoid action in bone. Ann NY Acad Sci 966: 73-81.

Chow A, Lucas D, Hidalgo A, Mendez-Ferrer S, Hashimoto D, Scheiermann C, Battista M, Leboeuf M, Prophete C, van Rooijen N, et al. 2011. Bone marrow $\mathrm{CD} 169^{+}$macrophages promote the retention of hematopoietic stem and progenitor cells in the mesenchymal stem cell niche. J Exp Med 208: 261-271.

Christopher MJ, Link DC. 2008. Granulocyte colony-stimulating factor induces osteoblast apoptosis and inhibits osteoblast differentiation. J Bone Miner Res 23: $1765-$ 1774.

Clevers H. 2011. The cancer stem cell: Premises, promises and challenges. Nat Med 17: 313-319.

Cordeiro Gomes A, Hara T, Lim VY, Herndler-Brandstetter D, Nevius E, Sugiyama T, Tani-ichi S, Schlenner S, Richie E, Rodewald HR, et al. 2016. Hematopoietic stem cell niches produce lineage-instructive signals to control multipotent progenitor differentiation. Immunity 45: 12191231.

Cornish J, Callon KE, Bava U, Kamona SA, Cooper GJS, Reid IR. 2001. Effects of calcitonin, amylin, and calcitonin gene-related peptide on osteoclast development. Bone 29: $162-168$.

Cornish J, Callon K, Bava U, Lin C, Naot D, Hill B, Grey A, Broom N, Myers D, Nicholson G, et al. 2002. Leptin directly regulates bone cell function in vitro and reduces bone fragility in vivo. J Endocrinol 175: 405-415.

Cronstein BN, Kimmel SC, Levin RI, Martiniuk F, Weissmann G. 1992. A mechanism for the antiinflammatory effects of corticosteroids: The glucocorticoid receptor regulates leukocyte adhesion to endothelial cells and expression of endothelial-leukocyte adhesion molecule 1 and intercellular adhesion molecule 1. Proc Natl Acad Sci 89: 9991-9995.

Cutolo M. 2012. Chronobiology and the treatment of rheumatoid arthritis. Curr Opin Rheumatol 24: 312-318.

De Felipe C, Herrero JF, O’Brien JA, Palmer JA, Doyle CA, Smith AJ, Laird JM, Belmonte C, Cervero F, Hunt SP. 1998. Altered nociception, analgesia and aggression in mice lacking the receptor for substance P. Nature 392: 394-397.

de Klein A, van Kessel AG, Grosveld G, Bartram CR, Hagemeijer A, Bootsma D, Spurr NK, Heisterkamp N, Groffen J, Stephenson JR. 1982. A cellular oncogene is translocated to the Philadelphia chromosome in chronic myelocytic leukaemia. Nature 300: 765-767.

Derijk RH, Schaaf MJ, Turner G, Datson NA, Vreugdenhil E, Cidlowski J, de Kloet ER, Emery P, Sternberg EM, DeteraWadleigh SD. 2001. A human glucocorticoid receptor gene variant that increases the stability of the glucocorticoid receptor $\beta$-isoform mRNA is associated with rheumatoid arthritis. J Rheumatol 28: 2383-2388.

Deutschman CS, Tracey KJ. 2014. Sepsis: Current dogma and new perspectives. Immunity 40: 463-475.

Dimitri P, Rosen C. 2017. The central nervous system and bone metabolism: An evolving story. Calcif Tissue Int 100: $476-485$.

Ding L, Morrison SJ. 2013. Haematopoietic stem cells and early lymphoid progenitors occupy distinct bone marrow niches. Nature 495: 231-235.
Ding Y, Arai M, Kondo H, Togari A. 2010. Effects of capsaicin-induced sensory denervation on bone metabolism in adult rats. Bone 46: 1591-1596.

Ding L, Saunders TL, Enikolopov G, Morrison SJ. 2012. Endothelial and perivascular cells maintain haematopoietic stem cells. Nature 481: 457-462.

Ducy P, Amling M, Takeda S, Priemel M, Schilling AF, Beil FT, Shen J, Vinson C, Rueger JM, Karsenty G. 2000. Leptin inhibits bone formation through a hypothalamic relay: A central control of bone mass. Cell 100: 197-207.

Duhrsen U, Hossfeld DK. 1996. Stromal abnormalities in neoplastic bone marrow diseases. Ann Hematol 73: 5370 .

Elefteriou F, Ahn JD, Takeda S, Starbuck M, Yang X, Liu X, Kondo H, Richards WG, Bannon TW, Noda M, et al. 2005. Leptin regulation of bone resorption by the sympathetic nervous system and CART. Nature 434: 514-520.

Elefteriou F, Campbell P, Ma Y. 2014. Control of bone remodeling by the peripheral sympathetic nervous system. Calcif Tissue Int 94: 140-151.

Entschladen F, Drell TL 4th, Lang K, Joseph J, Zaenker KS. 2004. Tumour-cell migration, invasion, and metastasis: Navigation by neurotransmitters. Lancet Oncol 5: 254258.

Erickson JC, Hollopeter G, Palmiter RD. 1996. Attenuation of the obesity syndrome of $o b / o b$ mice by the loss of neuropeptide Y. Science 274: 1704.

Feuer AJ, Demmer RT, Thai A, Vogiatzi MG. 2015. Use of selective serotonin reuptake inhibitors and bone mass in adolescents: An NHANES study. Bone 78: 28-33.

Frenette PSWL. 2000. Sulfated glycans induce rapid hematopoietic progenitor cell mobilization: Evidence for selectin-dependent and independent mechanisms. Blood 96: 2460-2468.

Frenette PS, Pinho S, Lucas D, Scheiermann C. 2013. Mesenchymal stem cell: Keystone of the hematopoietic stem cell niche and a stepping-stone for regenerative medicine. Ann Rev Immunol 31: 285-316.

Friedman JM, Halaas JL. 1998. Leptin and the regulation of body weight in mammals. Nature 395: 763-770.

Glaser R, Kiecolt-Glaser JK. 2005. Stress-induced immune dysfunction: Implications for health. Nat Rev Immunol 5: 243-251.

Goehler LE, Gaykema RP, Hansen MK, Anderson K, Maier SF, Watkins LR. 2000. Vagal immune-to-brain communication: A visceral chemosensory pathway. Auton Neurosci 85: 49-59.

Gong Y, Slee RB, Fukai N, Rawadi G, Roman-Roman S, Reginato AM, Wang H, Cundy T, Glorieux FH, Lev D, et al. 2001. LDL receptor-related protein 5 (LRP5) affects bone accrual and eye development. Cell 107: 513-523.

Gratwohl A, Baldomero H, Passweg J. 2013. Hematopoietic stem cell transplantation activity in Europe. Curr Opin Hematol 20: 485-493.

Green PG, Luo J, Heller PH, Levine JD. 1993. Further substantiation of a significant role for the sympathetic nervous system in inflammation. Neuroscience 55: 10371043.

Greenbaum A, Hsu YM, Day RB, Schuettpelz LG, Christopher MJ, Borgerding JN, Nagasawa T, Link DC. 2013. CXCL12 in early mesenchymal progenitors is required 
M. Maryanovich et al.

for haematopoietic stem-cell maintenance. Nature 495: 227-230.

Halaas JL, Gajiwala KS, Maffei M, Cohen SL, Chait BT, Rabinowitz D, Lallone RL, Burley SK, Friedman JM. 1995. Weight-reducing effects of the plasma protein encoded by the obese gene. Science 269: 543 .

Hanoun M, Zhang D, Mizoguchi T, Pinho S, Pierce H, Kunisaki Y, Lacombe J, Armstrong SA, Duhrsen U, Frenette PS. 2014. Acute myelogenous leukemia-induced sympathetic neuropathy promotes malignancy in an altered he matopoietic stem cell niche. Cell Stem Cell 15: 365-375.

Hanoun M, Maryanovich M, Arnal-Estapé A, Frenette PS 2015. Neural regulation of hematopoiesis, inflammation, and cancer. Neuron 86: 360-373.

Harle P, Mobius D, Carr DJ, Scholmerich J, Straub RH. 2005 An opposing time-dependent immune-modulating effect of the sympathetic nervous system conferred by altering the cytokine profile in the local lymph nodes and spleen of mice with type II collagen-induced arthritis. Arthritis Rheum 52: 1305-1313.

Hattori K, Heissig B, Tashiro K, Honjo T, Tateno M, Shieh JH, Hackett NR, Quitoriano MS, Crystal RG, Rafii S, et al. 2001. Plasma elevation of stromal cell-derived factor-1 induces mobilization of mature and immature hematopoietic progenitor and stem cells. Blood 97: 3354-3360.

Haus E, Smolensky MH. 1999. Biologic rhythms in the immune system. Chronobiol Int 16: 581-622.

Hill EL, Elde R. 1991. Distribution of CGRP-, VIP-, DßH-, SP-, and NPY-immunoreactive nerves in the periosteum of the rat. Cell Tissue Res 264: 469-480.

Horsnell H, Baldock PA. 2016. Osteoblastic actions of the neuropeptide Y system to regulate bone and energy homeostasis. Current Osteoporosis Rep 14: 26-31.

Ishikawa F, Yoshida S, Saito Y, Hijikata A, Kitamura H, Tanaka S, Nakamura R, Tanaka T, Tomiyama H, Saito $\mathrm{N}$, et al. 2007. Chemotherapy-resistant human AML stem cells home to and engraft within the bone-marrow endosteal region. Nat Biotech 25: 1315-1321.

Ishizuka K, Hirukawa K, Nakamura H, Togari A. 2005. Inhibitory effect of CGRP on osteoclast formation by mouse bone marrow cells treated with isoproterenol. Neurosci Lett 379: 47-51.

Itkin T, Gur-Cohen S, Spencer JA, Schajnovitz A, Ramasamy SK, Kusumbe AP, Ledergor G, Jung Y, Milo I, Poulos MG, et al. 2016. Distinct bone marrow blood vessels differentially regulate haematopoiesis. Nature 532: 323-328.

Jung WC, Levesque JP, Ruitenberg MJ. 2017. It takes nerve to fight back: The significance of neural innervation of the bone marrow and spleen for immune function. Semin Cell Dev Biol 61: 60-70.

Kajimura D, Hinoi E, Ferron M, Kode A, Riley KJ, Zhou B, Guo XE, Karsenty G. 2011. Genetic determination of the cellular basis of the sympathetic regulation of bone mass accrual. J Exp Med 208: 841.

Katayama Y, Battista M, Kao WM, Hidalgo A, Peired AJ, Thomas SA, Frenette PS. 2006. Signals from the sympathetic nervous system regulate hematopoietic stem cell egress from bone marrow. Cell 124: 407-421.

Kauschke V, Kneffel M, Floel W, Hartmann S, Kampschulte M, Dürselen L, Ignatius A, Schnettler R, Heiss C, Lips KS.
2015. Bone status of acetylcholinesterase-knockout mice. Int Immunopharmacol 29: 222-230.

Kiel MJ, Yilmaz ÖH, Iwashita T, Yilmaz OH, Terhorst C, Morrison SJ. 2005. SLAM family receptors distinguish hematopoietic stem and progenitor cells and reveal endothelial niches for stem cells. Cell 121: 1109-1121.

Kode A, Obri A, Paone R, Kousteni S, Ducy P, Karsenty G. 2014. Lrp5 regulation of bone mass and serotonin synthesis in the gut. Nat Med 20: 1228-1229.

Kralovics R, Passamonti F, Buser AS, Teo SS, Tiedt R, Passweg JR, Tichelli A, Cazzola M, Skoda RC. 2005. A gain-offunction mutation of JAK2 in myeloproliferative disorders. N Engl J Med 352: 1779-1790.

Kreso A, Dick JE. 2014. Evolution of the cancer stem cell model. Cell Stem Cell 14: 275-291.

Kuis W, de Jong-de Vos van Steenwijk C, Sinnema G, Kavelaars A, Prakken B, Helders PJ, Heijnen CJ. 1996. The autonomic nervous system and the immune system in juvenile rheumatoid arthritis. Brain Behav Immun 10: 387-398.

Kunisaki Y, Bruns I, Scheiermann C, Ahmed J, Pinho S, Zhang D, Mizoguchi T, Wei Q, Lucas D, Ito K, et al. 2013. Arteriolar niches maintain haematopoietic stem cell quiescence. Nature 502: 637-643.

Kuo LE, Kitlinska JB, Tilan JU, Li L, Baker SB, Johnson MD, Lee EW, Burnett MS, Fricke ST, Kvetnansky R, et al. 2007. Neuropeptide $\mathrm{Y}$ acts directly in the periphery on fat tissue and mediates stress-induced obesity and metabolic syndrome. Nat Med 13: 803-811.

Kusumbe AP, Ramasamy SK, Itkin T, Mäe MA, Langen UH, Betsholtz C, Lapidot T, Adams RH. 2016. Age-dependent modulation of vascular niches for haematopoietic stem cells. Nature 532: 380-384.

Lee YM, Fujiwara J, Munakata Y, Ishii T, Sugawara A, Kaku M, Kokubun S, Sasaki T, Funato T. 2004. A mutation of the glucocorticoid receptor gene in patients with systemic lupus erythematosus. Tohoku J Exp Med 203: 69-76.

Lee NJ, Doyle KL, Sainsbury A, Enriquez RF, Hort YJ, Riepler SJ, Baldock PA, Herzog H. 2010. Critical role for Y1 receptors in mesenchymal progenitor cell differentiation and osteoblast activity. J Bone Miner Res 25: 1736-1747.

Liang W, Zhuo X, Tang Z, Wei X, Li B. 2015. Calcitonin gene-related peptide stimulates proliferation and osteogenic differentiation of osteoporotic rat-derived bone mesenchymal stem cells. Mol Cell Biochem 402: 101-110.

Little RD, Folz C, Manning SP, Swain PM, Zhao SC, Eustace B, Lappe MM, Spitzer L, Zweier S, Braunschweiger K, et al. 2002. A mutation in the LDL receptor-related protein 5 gene results in the autosomal dominant high-bonemass trait. Am J Hum Genet 70: 11-19.

Liu K, Castillo MD, Murthy RG, Patel N, Rameshwar P. 2007. Tachykinins and hematopoiesis. Clinica Chimica Acta 385: 28-34.

Liu PS, Chen YY, Feng CK, Lin YH, Yu TC. 2011. Muscarinic acetylcholine receptors present in human osteoblast and bone tissue. Eur J Pharmacol 650: 34-40.

Lucas D, Battista M, Shi PA, Isola L, Frenette PS. 2008. Mobilized hematopoietic stem cell yield depends on species-specific circadian timing. Cell Stem Cell 3: 364-366.

Lucas D, Scheiermann C, Chow A, Kunisaki Y, Bruns I, Barrick C, Tessarollo L, Frenette PS. 2013. Chemothera- 
py-induced bone marrow nerve injury impairs hematopoietic regeneration. Nat Med 19: 695-703.

Lundberg P, Allison SJ, Lee NJ, Baldock PA, Brouard N, Rost S, Enriquez RF, Sainsbury A, Lamghari M, Simmons P, et al. 2007. Greater bone formation of Y2 knockout mice is associated with increased osteoprogenitor numbers and altered Y1 receptor expression. J Biol Chem 282: 19082 19091.

Mach DB, Rogers SD, Sabino MC, Luger NM, Schwei MJ, Pomonis JD, Keyser CP, Clohisy DR, Adams DJ, O’Leary P, et al. 2002. Origins of skeletal pain: Sensory and sympathetic innervation of the mouse femur. Neuroscience 113: $155-166$.

Maestroni GJ, Cosentino M, Marino F, Togni M, Conti A, Lecchini S, Frigo G. 1998. Neural and endogenous catecholamines in the bone marrow. Circadian association of norepinephrine with hematopoiesis? Exp Hematol 26: 1172-1177.

Magnon C, Hall SJ, Lin J, Xue X, Gerber L, Freedland SJ, Frenette PS. 2013. Autonomic nerve development contributes to prostate cancer progression. Science 341: 1236361.

Manolagas SC. 2000. Birth and death of bone cells: Basic regulatory mechanisms and implications for the pathogenesis and treatment of osteoporosis. Endocr Rev 21: 115-137.

Matyszak MK, Citterio S, Rescigno M, Ricciardi-Castagnoli P. 2000. Differential effects of corticosteroids during different stages of dendritic cell maturation. Eur J Immunol 30: 1233-1242.

Mendelson A, Frenette PS. 2014. Hematopoietic stem cell niche maintenance during homeostasis and regeneration. Nat Med 20: 833-846.

Mendez-Ferrer S, Lucas D, Battista M, Frenette PS. 2008. Haematopoietic stem cell release is regulated by circadian oscillations. Nature 452: 442-447.

Mendez-Ferrer S, Battista M, Frenette PS. 2010a. Cooperation of $\beta 2$ - and $\beta 3$-adrenergic receptors in hematopoietic progenitor cell mobilization. Ann NY Acad Sci 1192: 139144.

Mendez-Ferrer S, Michurina TV, Ferraro F, Mazloom AR, Macarthur BD, Lira SA, Scadden DT, Maayan A, Enikolopov GN, Frenette PS. 2010b. Mesenchymal and haematopoietic stem cells form a unique bone marrow niche. Nature 466: 829-834.

Miyamasu M, Misaki Y, Izumi S, Takaishi T, Morita Y, Nakamura H, Matsushima K, Kasahara T, Hirai K. 1998. Glucocorticoids inhibit chemokine generation by human eosinophils. J Allergy Clin Immunol 101: 75-83.

Muthu K, Iyer S, He LK, Szilagyi A, Gamelli RL, Shankar R, Jones SB. 2007. Murine hematopoietic stem cells and progenitors express adrenergic receptors. J Neuroimmunol 186: $27-36$.

Nance DM, Sanders VM. 2007. Autonomic innervation and regulation of the immune system (1987-2007). Brain Behav Immun 21: 736-745.

Nilsson SK, Johnston HM, Whitty GA, Williams B, Webb RJ, Denhardt DT, Bertoncello I, Bendall LJ, Simmons PJ, Haylock DN. 2005. Osteopontin, a key component of the hematopoietic stem cell niche and regulator of primitive hematopoietic progenitor cells. Blood 106: 1232-1239.
Neural Regulation of Bone and Bone Marrow

Norton WT, Cammer W. 1984. Isolation and characterization of myelin. In Myelin (ed. Morell P). Plenum, New York.

Nowicki M, Ostalska-Nowicka D, Kondraciuk B, Miskowiak B. 2007. The significance of substance $P$ in physiological and malignant haematopoiesis. J Clin Pathol 60: 749-755.

Offley SC, Guo TZ, Wei T, Clark JD, Vogel H, Lindsey DP, Jacobs CR, Yao W, Lane NE, Kingery WS. 2005. Capsaicin-sensitive sensory neurons contribute to the maintenance of trabecular bone integrity. J Bone Miner Res 20: 257-267.

Oh J, Lee YD, Wagers AJ. 2014. Stem cell aging: Mechanisms, regulators and therapeutic opportunities. Nat Med 20: 870-880.

Park MH, Jin HK, Min WK, Lee WW, Lee JE, Akiyama H, Herzog H, Enikolopov GN, Schuchman EH, Bae JS. 2015. Neuropeptide Y regulates the hematopoietic stem cell microenvironment and prevents nerve injury in the bone marrow. EMBO J 34: 1648

Park MH, Lee JK, Kim N, Min WK, Lee JE, Kim KT, Akiyama H, Herzog H, Schuchman EH, Jin HK, et al. 2016. Neuropeptide Y induces hematopoietic stem/progenitor cell mobilization by regulating matrix metalloproteinase-9 activity through Y1 receptor in osteoblasts. Stem Cells 34: 2145-2156.

Passaro D, Di Tullio A, Abarrategi A, Rouault-Pierre K, Foster K, Ariza-McNaughton L, Montaner B, Chakravarty P, Bhaw L, Diana G, et al. 2017. Increased vascular permeability in the bone marrow microenvironment contributes to disease progression and drug response in acute myeloid leukemia. Cancer Cell 32: 324-341.

Passegue E, Jamieson CH, Ailles LE, Weissman IL. 2003. Normal and leukemic hematopoiesis: Are leukemias a stem cell disorder or a reacquisition of stem cell characteristics? Proc Natl Acad Sci 100: 11842-11849.

Pece S, Tosoni D, Confalonieri S, Mazzarol G, Vecchi M, Ronzoni S, Bernard L, Viale G, Pelicci PG, Di Fiore PP. 2010. Biological and molecular heterogeneity of breast cancers correlates with their cancer stem cell content. Cell 140: 62-73.

Pereira A, Cervantes F, Brugues R, Rozman C. 1990. Bone marrow histopathology in primary myelofibrosis: Clinical and haematologic correlations and prognostic evaluation. Eur J Haematol 44: 95-99.

Petit I, Szyper-Kravitz M, Nagler A, Lahav M, Peled A, Habler L, Ponomaryov T, Taichman RS, Arenzana-Seisdedos F, Fujii N, et al. 2002. G-CSF induces stem cell mobilization by decreasing bone marrow SDF- 1 and up-regulating CXCR4. Nat Immunol 3: 687-694.

Pierce H, Zhang D, Magnon C, Lucas D, Christin JR, Hug gins M, Schwartz GJ, Frenette PS. 2017. Cholinergic signals from the CNS regulate G-CSF-mediated HSC mobilization from bone marrow via a glucocorticoid signaling relay. Cell Stem Cell 20: 648-658.e644.

Pinho S, Lacombe J, Hanoun M, Mizoguchi T, Bruns I, Kunisaki Y, Frenette PS. 2013. PDGFR $\alpha$ and CD51 mark human nestin ${ }^{+}$sphere-forming mesenchymal stem cells capable of hematopoietic progenitor cell expansion. J Exp Med 210: 1351-1367.

Pongratz G, Straub RH. 2013. Role of peripheral nerve fibres in acute and chronic inflammation in arthritis. Nat Rev Rheumatol 9: 117-126. 
M. Maryanovich et al.

Puram RV, Kowalczyk MS, de Boer CG, Schneider RK, Miller PG, McConkey M, Tothova Z, Tejero H, Heckl D, Jaras $M$, et al. 2016. Core circadian clock genes regulate leukemia stem cells in AML. Cell 165: 303-316.

Rameshwar P, Gascon P. 1995. Substance P (SP) mediates production of stem cell factor and interleukin-1 in bone marrow stroma: Potential autoregulatory role for these cytokines in SP receptor expression and induction. Blood 86: 482.

Rauma PH, Honkanen RJ, Williams LJ, Tuppurainen MT, Kröger HP, Koivumaa-Honkanen H. 2016. Effects of antidepressants on postmenopausal bone loss-A 5-year longitudinal study from the OSTPRE cohort. Bone 89: 25-31.

Revollo JR, Cidlowski JA. 2009. Mechanisms generating diversity in glucocorticoid receptor signaling. Ann NY Acad Sci 1179: 167-178

Reynaud D, Pietras E, Barry-Holson K, Mir A, Binnewies M, Jeanne M, Sala-Torra O, Radich JP, Passegue E. 2011. IL-6 controls leukemic multipotent progenitor cell fate and contributes to chronic myelogenous leukemia development. Cancer Cell 20: 661-673.

Roesch A, Fukunaga-Kalabis M, Schmidt EC, Zabierowski SE, Brafford PA, Vultur A, Basu D, Gimotty P, Vogt T, Herlyn M. 2010. A temporarily distinct subpopulation of slow-cycling melanoma cells is required for continuous tumor growth. Cell 141: 583-594.

Rowley JD. 1973. Letter: A new consistent chromosomal abnormality in chronic myelogenous leukaemia identified by quinacrine fluorescence and Giemsa staining. $\mathrm{Na}-$ ture 243: 290-293.

Saeed RW, Varma S, Peng-Nemeroff T, Sherry B, Balakhaneh D, Huston J, Tracey KJ, Al-Abed Y, Metz CN. 2005. Cholinergic stimulation blocks endothelial cell activation and leukocyte recruitment during inflammation. J Exp Med 201: 1113-1123.

Saito Y, Uchida N, Tanaka S, Suzuki N, Tomizawa-Murasawa M, Sone A, Najima Y, Takagi S, Aoki Y, Wake A, et al. 2010. Induction of cell cycle entry eliminates human leukemia stem cells in a mouse model of AML. Nat Biotechnol 28: 275-280.

Schafer MK, Eiden LE, Weihe E. 1998. Cholinergic neurons and terminal fields revealed by immunohistochemistry for the vesicular acetylcholine transporter. II: The peripheral nervous system. Neuroscience 84: 361-376.

Schafers M, Svensson CI, Sommer C, Sorkin LS. 2003. Tumor necrosis factor- $\alpha$ induces mechanical allodynia after spinal nerve ligation by activation of p38 MAPK in primary sensory neurons. J Neurosci 23: 2517-2521.

Scheiermann C, Kunisaki Y, Lucas D, Chow A, Jang JE, Zhang D, Hashimoto D, Merad M, Frenette PS. 2012 Adrenergic nerves govern circadian leukocyte recruitment to tissues. Immunity 37: 290-301.

Scheiermann C, Kunisaki Y, Frenette PS. 2013. Circadian control of the immune system. Nat Rev Immunol 13: 190-198.

Schepers K, Pietras EM, Reynaud D, Flach J, Binnewies M, Garg T, Wagers AJ, Hsiao EC, Passegue E. 2013. Myeloproliferative neoplasia remodels the endosteal bone marrow niche into a self-reinforcing leukemic niche. Cell Stem Cell 13: 285-299.
Schmitt JAJ, Wingen M, Ramaekers JG, Evers EAT, Riedel WJ. 2006. Serotonin and human cognitive performance. Curr Pharmaceutical Design 12: 2473-2486.

Schwartzman RJ. 2000. New treatments for reflex sympathetic dystrophy. N Engl J Med 343: 654-656.

Semerad CL, Christopher MJ, Liu F, Short B, Simmons PJ, Winkler I, Levesque JP, Chappel J, Ross FP, Link DC. 2005. G-CSF potently inhibits osteoblast activity and CXCL12 mRNA expression in the bone marrow. Blood 106: 3020-3027.

Sheu Yh, Lanteigne A, Stürmer T, Pate V, Azrael D, Miller M. 2015. SSRI use and risk of fractures among perimenopausal women without mental disorders. Injury Prevention 21: 397.

Shi Y, Oury F, Yadav VK, Wess J, Liu XS, Guo XE, Murshed M, Karsenty G. 2010. Signaling through the M3 muscarinic receptor favors bone mass accrual by decreasing sympathetic activity. Cell Metab 11: 231-238.

Siclari VA, Zhu J, Akiyama K, Liu F, Zhang X, Chandra A, Nah HD, Shi S, Qin L. 2013. Mesenchymal progenitors residing close to the bone surface are functionally distinct from those in the central bone marrow. Bone 53: 575-586.

Sivaraj KK, Adams RH. 2016. Blood vessel formation and function in bone. Development 143: 2706.

Spiegel A, Shivtiel S, Kalinkovich A, Ludin A, Netzer N, Goichberg P, Azaria Y, Resnick I, Hardan I, Ben-Hur H, et al. 2007. Catecholaminergic neurotransmitters regulate migration and repopulation of immature human $\mathrm{CD} 34^{+}$ cells through Wnt signaling. Nat Immunol 8: 1123-1131.

Stanley BG, Kyrkouli SE, Lampert S, Leibowitz SF. 1986. Neuropeptide Y chronically injected into the hypothalamus: A powerful neurochemical inducer of hyperphagia and obesity. Peptides 7: 1189-1192.

Sternberg EM. 2006. Neural regulation of innate immunity: A coordinated nonspecific host response to pathogens. Nat Rev Immunol 6: 318-328.

Stier S, Ko Y, Forkert R, Lutz C, Neuhaus T, Grünewald E, Cheng T, Dombkowski D, Calvi LM, Rittling SR, et al. 2005. Osteopontin is a hematopoietic stem cell niche component that negatively regulates stem cell pool size. J Exp Med 201: 1781-1791.

Sugiyama T, Kohara H, Noda M, Nagasawa T. 2006. Maintenance of the hematopoietic stem cell pool by CXCL12CXCR4 chemokine signaling in bone marrow stromal cell niches. Immunity 25: 977-988.

Sweeney EA, Priestley GV, Nakamoto B, Collins RG, Beau$\operatorname{det}$ AL, Papayannopoulou T. 2000. Mobilization of stem/ progenitor cells by sulfated polysaccharides does not require selectin presence. Proc Natl Acad Sci 97: 6544-6549.

Takeda S, Elefteriou F, Levasseur R, Liu X, Zhao L, Parker KL, Armstrong D, Ducy P, Karsenty G. 2002. Leptin regulates bone formation via the sympathetic nervous system. Cell 111: 305-317.

Thomas T, Gori F, Khosla S, Jensen MD, Burguera B, Riggs BL. 1999. Leptin acts on human marrow stromal cells to enhance differentiation to osteoblasts and to inhibit differentiation to adipocytes. Endocrinology 140: 16301638 .

Tiedt R, Hao-Shen H, Sobas MA, Looser R, Dirnhofer S, Schwaller J, Skoda RC. 2008. Ratio of mutant JAK2- 
V617F to wild-type Jak2 determines the MPD phenotypes in transgenic mice. Blood 111: 3931-3940.

Torres-Rosas R, Yehia G, Pena G, Mishra P, del Rocio Thompson-Bonilla M, Moreno-Eutimio MA, Arriaga-Pizano LA, Isibasi A, Ulloa L. 2014. Dopamine mediates vagal modulation of the immune system by electroacupuncture. Nat Med 20: 291-295.

Vedhara K, Cox NK, Wilcock GK, Perks P, Hunt M, Anderson S, Lightman SL, Shanks NM. 1999. Chronic stress in elderly carers of dementia patients and antibody response to influenza vaccination. Lancet 353: 627-631.

Vida G, Pena G, Kanashiro A, Thompson-Bonilla MdR, Palange D, Deitch EA, Ulloa L. 2011. $\beta 2$-Adrenoreceptors of regulatory lymphocytes are essential for vagal neuromodulation of the innate immune system. FASEB J 25: 4476-4485.

Walther DJ, Peter JU, Bashammakh S, Hörtnagl H, Voits M, Fink H, Bader M. 2003. Synthesis of serotonin by a second tryptophan hydroxylase isoform. Science 299: 76.

Wang H, Yu M, Ochani M, Amella CA, Tanovic M, Susarla S, Li JH, Wang H, Yang H, Ulloa L, et al. 2003. Nicotinic acetylcholine receptor $\alpha 7$ subunit is an essential regulator of inflammation. Nature 421: 384-388.

Wang L, Shi X, Zhao R, Halloran BP, Clark DJ, Jacobs CR Kingery WS. 2010. Calcitonin-gene-related peptide stimulates stromal cell osteogenic differentiation and inhibits RANKL induced NF- $\kappa \mathrm{B}$ activation, osteoclastogenesis and bone resorption. Bone 46: 1369-1379.

Warden SJ, Haney EM. 2008. Skeletal effects of serotonin (5hydroxytryptamine) transporter inhibition: Evidence from in vitro and animal-based studies. J Musculoskelet Neuronal Interact 8: 121-132.

Warden SJ, Robling AG, Haney EM, Turner CH, Bliziotes MM. 2010. The emerging role of serotonin (5-hydroxytryptamine) in the skeleton and its mediation of the skeletal effects of low-density lipoprotein receptor-related protein 5 (LRP5). Bone 46: 4-12.

Wee NKY, Kulkarni RN, Horsnell H, Baldock PA. 2016. The brain in bone and fuel metabolism. Bone 82: 56-63.

Wilson A, Laurenti E, Trumpp A. 2009. Balancing dormant and self-renewing hematopoietic stem cells. Curr Opin Genet Dev 19: 461-468.

Wiseman DH. 2011. Donor cell leukemia: A review. Biol Blood Marrow Transplant 17: 771-789.

Woltman AM, Massacrier C, de Fijter JW, Caux C, van Kooten C. 2002. Corticosteroids prevent generation of $\mathrm{CD} 34^{+}$-derived dermal dendritic cells but do not inhibit Langerhans cell development. J Immunol 168: 61816188 .

Yadav VK, Ryu JH, Suda N, Tanaka KF, Gingrich JA, Schütz G, Glorieux FH, Chiang CY, Zajac JD, Insogna KL, et al.
Neural Regulation of Bone and Bone Marrow

2008. Lrp 5 controls bone formation by inhibiting serotonin synthesis in the duodenum. Cell 135: 825-837.

Yadav VK, Oury F, Suda N, Liu ZW, Gao XB, Confavreux C, Klemenhagen KC, Tanaka KF, Gingrich JA, Guo XE, et al. 2009. A serotonin-dependent mechanism explains the leptin regulation of bone mass, appetite, and energy expenditure. Cell 138: 976-989.

Yamazaki K, Allen TD. 1990. Ultrastructural morphometric study of efferent nerve terminals on murine bone marrow stromal cells, and the recognition of a novel anatomical unit: The "neuro-reticular complex." Am J Anat 187: 261276.

Yamazaki S, Ema H, Karlsson G, Yamaguchi T, Miyoshi H, Shioda S, Taketo MM, Karlsson S, Iwama A, Nakauchi H. 2011. Nonmyelinating Schwann cells maintain hematopoietic stem cell hibernation in the bone marrow niche. Cell 147: 1146-1158.

Yoshino K, Suzuki M, Kawarai Y, Sakuma Y, Inoue G, Orita S, Yamauchi K, Aoki Y, Ishikawa T, Miyagi M, et al. 2014. Increase of TRPV1-immunoreactivity in dorsal root ganglia neurons innervating the femur in a rat model of osteoporosis. Yonsei Med J 55: 1600-1605.

Yue R, Zhou BO, Shimada IS, Zhao Z, Morrison SJ. 2016. Leptin receptor promotes adipogenesis and reduces osteogenesis by regulating mesenchymal stromal cells in adult bone marrow. Cell Stem Cell 18: 782-796.

Zaidi M, Fuller K, Bevis PJR, Gaines Das RE, Chambers TJ, MacIntyre I. 1987. Calcitonin gene-related peptide inhibits osteoclastic bone resorption: A comparative study. Calcif Tissue Int 40: 149-154.

Zhang Y, Proenca R, Maffei M, Barone M, Leopold L, Friedman JM. 1994. Positional cloning of the mouse obese gene and its human homologue. Nature 372: 425-432.

Zhang J, Niu C, Ye L, Huang H, He X, Tong WG, Ross J, Haug J, Johnson T, Feng JQ, et al. 2003. Identification of the haematopoietic stem cell niche and control of the niche size. Nature 425: 836-841.

Zhang B, Ho Yin W, Huang Q, Maeda T, Lin A, Lee Su, Hair A, Holyoake TL, Huettner C, Bhatia R. 2012. Altered microenvironmental regulation of leukemic and normal stem cells in chronic myelogenous leukemia. Cancer Cell 21: 577-592.

Zhang B, Chu S, Agarwal P, Campbell VL, Hopcroft L, Jorgensen HG, Lin A, Gaal K, Holyoake TL, Bhatia R. 2016 Inhibition of interleukin-1 signaling enhances elimination of tyrosine kinase inhibitor-treated CML stem cells. Blood 128: 2671-2682.

Zhu J, Garrett R, Jung Y, Zhang Y, Kim N, Wang J, Joe GJ, Hexner E, Choi Y, Taichman RS, et al. 2007. Osteoblasts support B-lymphocyte commitment and differentiation from hematopoietic stem cells. Blood 109: 3706-3712. 


\section{$\&_{\mathrm{CSH}}^{\infty} \&$ Cold Spring Harbor

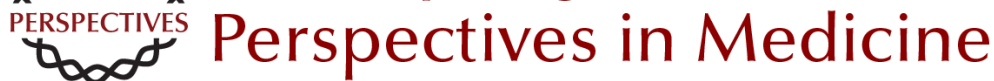

\section{Neural Regulation of Bone and Bone Marrow}

Maria Maryanovich, Shoichiro Takeishi and Paul S. Frenette

Cold Spring Harb Perspect Med 2018; doi: 10.1101/cshperspect.a031344 originally published online March 2, 2018

\section{Subject Collection Bone: A Regulator of Physiology}

\section{Mechanism of Bone Mineralization} Monzur Murshed

Neural Regulation of Bone and Bone Marrow Maria Maryanovich, Shoichiro Takeishi and Paul S. Frenette

Regulation of Bone Remodeling by Parathyroid Hormone Marc N. Wein and Henry M. Kronenberg

The Bone Marrow Microenvironment in Health and Myeloid Malignancy

Marta Galán-Díez, Álvaro Cuesta-Domínguez and Stavroula Kousteni

The Biology of Bone Metastasis

Mark Esposito, Theresa Guise and Yibin Kang

\section{Bone Remodeling and the Microbiome} Roberto Pacifici
Osteoimmunology
Kazuo Okamoto and Hiroshi Takayanagi

Multiple Myeloma and Bone: The Fatal Interaction Silvia Marino and G. David Roodman

Biology of Bone: The Vasculature of the Skeletal System

Emma C. Watson and Ralf H. Adams

Regulation of Energy Metabolism by

Bone-Derived Hormones

Paula Mera, Mathieu Ferron and Ioanna Mosialou

\section{Biology of Fibroblast Growth Factor 23: From \\ Physiology to Pathology \\ Marie Courbebaisse and Beate Lanske}

Regulation of Bone Metabolism by Sex Steroids Sundeep Khosla and David G. Monroe

For additional articles in this collection, see http://perspectivesinmedicine.cshlp.org/cgi/collection/ 